STATE OF NEVADA

AGENCY FOR NUCLEAR PROJECTS

NUCLEAR WASTE PROJECT

DOE/NV/10461- -T78
NWPO-TR-024-95

THE ROLE OF FRACTURE COATINGS ON

WATER IMBIBITION INTO UNSATURATED TUFF

FROM YUCCA MOUNTAIN

\author{
by \\ Vijay S. Chekuri, Scott W. Tyler, and John W. Fordham \\ Water Resources Center \\ Desert Research Institute \\ University and Community College System of Nevada
}

November 1995

The Nevada Agency for Nuclear Projects/Nuclear Waste Project Office (NWPO) was created by the Nevada Legislature to oversee federal high-level nuclear waste activities in the State. Since 1985, it has dealt largely with the U.S. Department of Energy's siting of a high-level nuclear waste repository at Yucca Mountain in southern Nevada. As part of its oversight role, NWPO has contracted for studies of various technical questions at the Yucca Mountain Project. 


\section{DISCLAIMER}

Portions of this document may be illegible in electronic image products. Images are produced from the best available original document. 


\section{DISCLAIMER}

This report was prepared as an account of work sponsored by an agency of the United States Government. Neither the United States Government nor any agency thereof, nor any of their employees, makes any warranty, express or implied, or assumes any legal liability or responsibility for the accuracy, completeness, or usefulness of any information, apparatus, product, or process disclosed, or represents that its use would not infringe privately owned rights. Reference herein to any specific commercial product, process, or service by trade name, trademark, manufacturer, or otherwise does not necessarily constitute or imply its endorsement, recommendation, or favoring by the United States Government or any agency thereof. The views and opinions of authors expressed herein do not necessarily state or reflect those of the United States Government or any agency thereof. 


\title{
THE ROLE OF FRACTURE COATINGS ON WATER IMBIBITION INTO UNSATURATED TUFF FROM YUCCA MOUNTAIN
}

\author{
by \\ Vijay S. Chekuri and Scott W. Tyler \\ Water Resources Center \\ Desert Research Institute \\ University and Community College System of Nevada
}

November 1995

The work upon which this report is based was supported by the Nevada Agency for Nuclear Projects/Nuclear Waste Management Officer under U.S. Department of Energy grant \#DE-FG08-85NV10461. 


\begin{abstract}
Studies dealing with fracture flow at Yucca Mountain have generally assumed that any water flowing down in a fracture will be absorbed by the porous matrix. However, a thin lining of low permeability material on the fracture walls may significantly impede imbibition into the matrix of unsaturated tuff. In this research, imbibition was measured across the fracture surfaces in the laboratory. Samples were collected from surface outcrops of Tiva Canyon and Topopah Spring members of the Paintbrush tuff near Yucca Mountain. Sorptivity, a convenient measure of imbibition, was used to investigate the changes in hydraulic properties as a result of fracture coatings. Results from experimental analysis of Topopah Spring tuff showed decreased sorptivity across coated fracture surfaces. Statistically, the coatings on the Tiva Canyon samples do not significantly affect sorptivity. Scanning Electron Microscope analysis shows that coatings on the Tiva Canyon samples are made up of iron, aluminum and to some extent magnesium. Coating material on the Topopah Spring samples is made up of calcium, magnesium, aluminum and iron. Coating significantly reduces the sorptivity for the Topopah Spring tuff. Numerical results are presented to show the effect of fracture coatings on water infiltration down a vertical fracture in simulated tuff. For the Topopah Spring tuff, the wetting front in the coated fracture travels deeper in the fracture and less into the matrix compared to the wetting front in the uncoated fracture. For the Tiva Canyon tuff, the wetting front in the uncoated fracture travels deeper in the fracture and less into the matrix as compared to the wetting front in the coated fracture.
\end{abstract}




\section{CONTENTS}

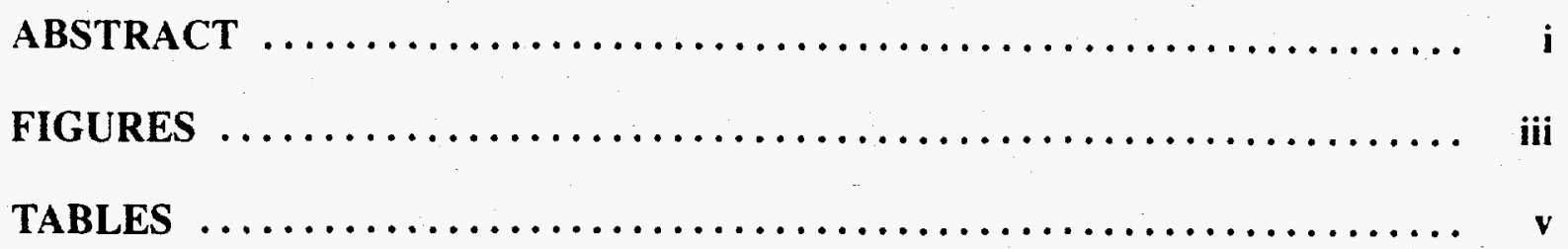

CHAPTER 1: INTRODUCTION $\ldots \ldots \ldots \ldots \ldots \ldots \ldots \ldots \ldots \ldots \ldots \ldots, 1$

CHAPTER 2: STUDIES OF IMBIBITION IN FRACTURED ROCKS $\ldots \ldots \ldots, 3$

CHAPTER 3: METHODS OF ANALYSES $\ldots \ldots \ldots \ldots \ldots \ldots \ldots \ldots \ldots \ldots, 8$

LABORATORY ANALYSIS $\ldots \ldots \ldots \ldots \ldots \ldots \ldots \ldots \ldots \ldots \ldots \ldots \ldots \ldots \ldots \ldots$

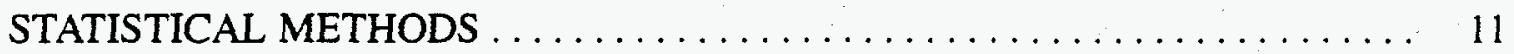

FRACTURE SURFACE ANALYSIS $\ldots \ldots \ldots \ldots \ldots \ldots \ldots \ldots \ldots \ldots \ldots, 11$

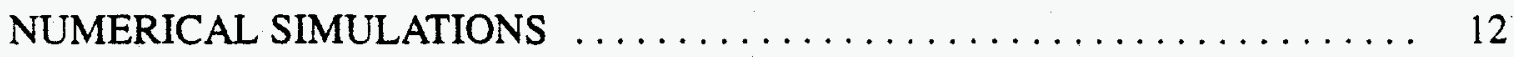

CHAPTER 4: RESULTS AND DISCUSSION $\ldots \ldots \ldots \ldots \ldots \ldots \ldots \ldots \ldots, 14$

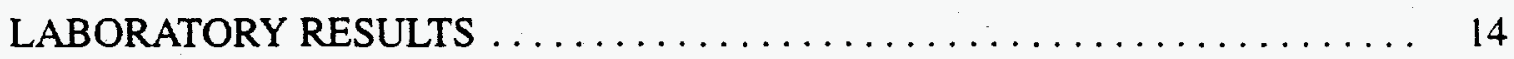

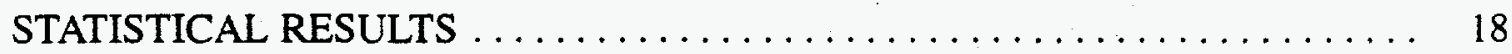

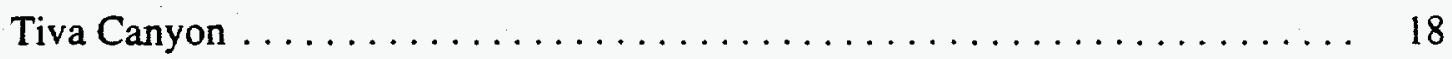

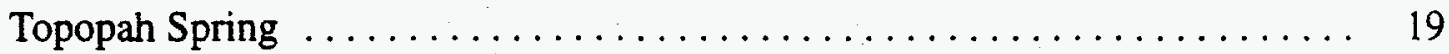

SCANNING ELECTRON MICROSCOPE (SEM) $\ldots \ldots \ldots \ldots \ldots \ldots \ldots .20$

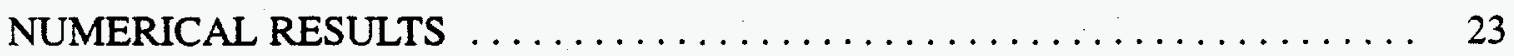

Model Input Data .............................. 23

CHAPTER 5: CONCLUSIONS $\ldots \ldots \ldots \ldots \ldots \ldots \ldots \ldots \ldots \ldots \ldots \ldots \ldots, 37$

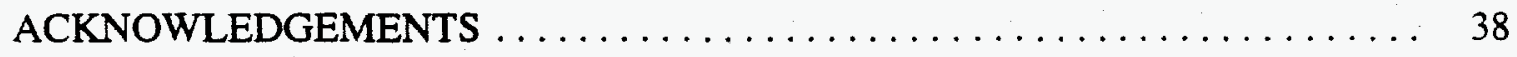

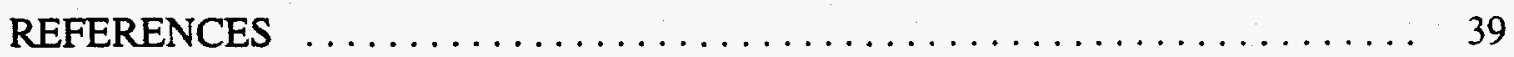




\section{FIGURES}

1. Location map of Yucca Mountain

2. Imbibiton versus time and square root time showing lower imbibition and lower sorptivity across a coated surface ................... 4

3. Three zones in the tuff matrix corresponding to three flow periods. . . . . . . 6

4. Regional map of Yucca Mountain showing locations where Tiva Canyon Tuff and Topopah Spring Tuff samples were collected.

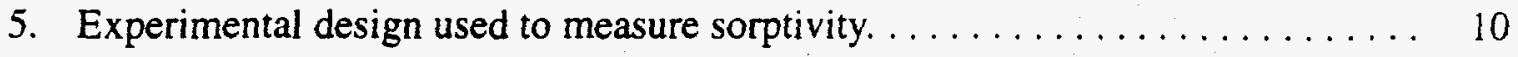

6. Imbibition experiment with a steel body which displayed no imbibition. ..... 10

7. Conceptual model showing various boundary conditions. $\ldots \ldots \ldots \ldots \ldots, 12$

8. Coated versus uncoated sorptivities for all Tiva Canyon samples investigated. .. 15

9. Comparison of sorptivities for samples where imbibition was perpendicular to the bedding plane.

10. Comparison of sorptivities for samples in which both imbibition directions (coated and uncoated) were parallel to the bedding direction.

11. Coated versus uncoated sorptivities for all Topopah Spring samples investigated.

12. SEM images of uncoated fracture surfaces for Tiva Canyon (12a) and

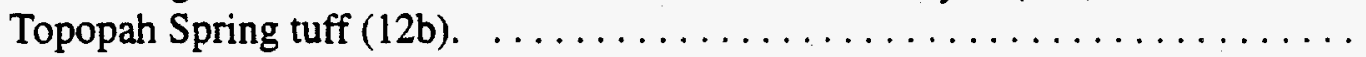

13. SEM images of coated surfaces of Tiva Canyon tuff (13a) and Topopah Spring tuff (13b).

14. Energy Dispersive X-Ray Spectrum for coated and uncoated samples of Tiva Canyon tuff.

15. Energy Dispersive X-Ray Spectrum for coated and uncoated samples of Topopah Spring tuff.

16. Energy Dispersive X-Ray Spectrum of Topopah Spring tuff coated sample showing high calcium content.

17. Comparison of simulated imbibition with experimental sorptivity data for a sample of Tiva Canyon coated fracture surface.

18. Comparison of simulated imbibition with average experimental sorptivity data for a sample of Tiva Canyon uncoated fracture surface.

19. Comparison of simulated imbibition with average experimental sorptivity data for a sample of Topopah Spring coated fracture surface. 
20. Comparison of simulated imbibition with average experimental sorptivity data for a sample of Topopah Spring uncoated fracture surface.

21. Retention model for the fracture used in simulations of both Tiva Canyon and Topopah Spring tuffs

22. Water retention data using van Genuchten hydraulic property parameters for the Topopah Spring tuff used in the simulation.

23. Water retention data using van Genuchten hydraulic property parameters for Tiva Canyon tuff used in the simulation.

24. Depth versus time plot of infiltrating water in the Topopah Spring fracture showing lower depth of infiltration for uncoated fracture.

25. Depth versus time plot of infiltrating water in the Tiva Canyon fracture showing lower depth of infiltration for coated fracture.

26. Water saturation distribution in the Topopah Spring tuff after two hours of infiltration (fracture apature corresponds to 12 microns).

27. Water saturation distribution in the Tiva Canyon tuff after two hours of infiltration (fracture apature corresponds to 12 microns). 


\section{TABLES}

1. Calculated Sorptivity Values for Tiva Canyon Tuff Samples. ............ 14

2. Calculated Sorptivity Values for Topopah Spring Tuff Samples. .......... 18

3. Least Square Means of $2 \times 2$ Factorial Design and Their P Values. . . . . . . . 20

4. Matrix Model Parameters. ................................ 29 


\section{CHAPTER 1 \\ INTRODUCTION}

The unsaturated zone at Yucca Mountain, located in southwest Nevada (Figure 1), is being considered as a potential site for high-level radioactive waste disposal. The rock being considered as the host for the proposed repository is the Topopah Spring member of the Paintbrush tuff, a densely welded ash-flow tuff (U.S. DOE, 1988). Suitability as a repository site depends in part on the nature of water movement through the unsaturated rock mass and imbibition of water from rock fractures into the matrix is a key process that controls the movement of water through the repository horizon (Nitao and Buscheck, 1991).

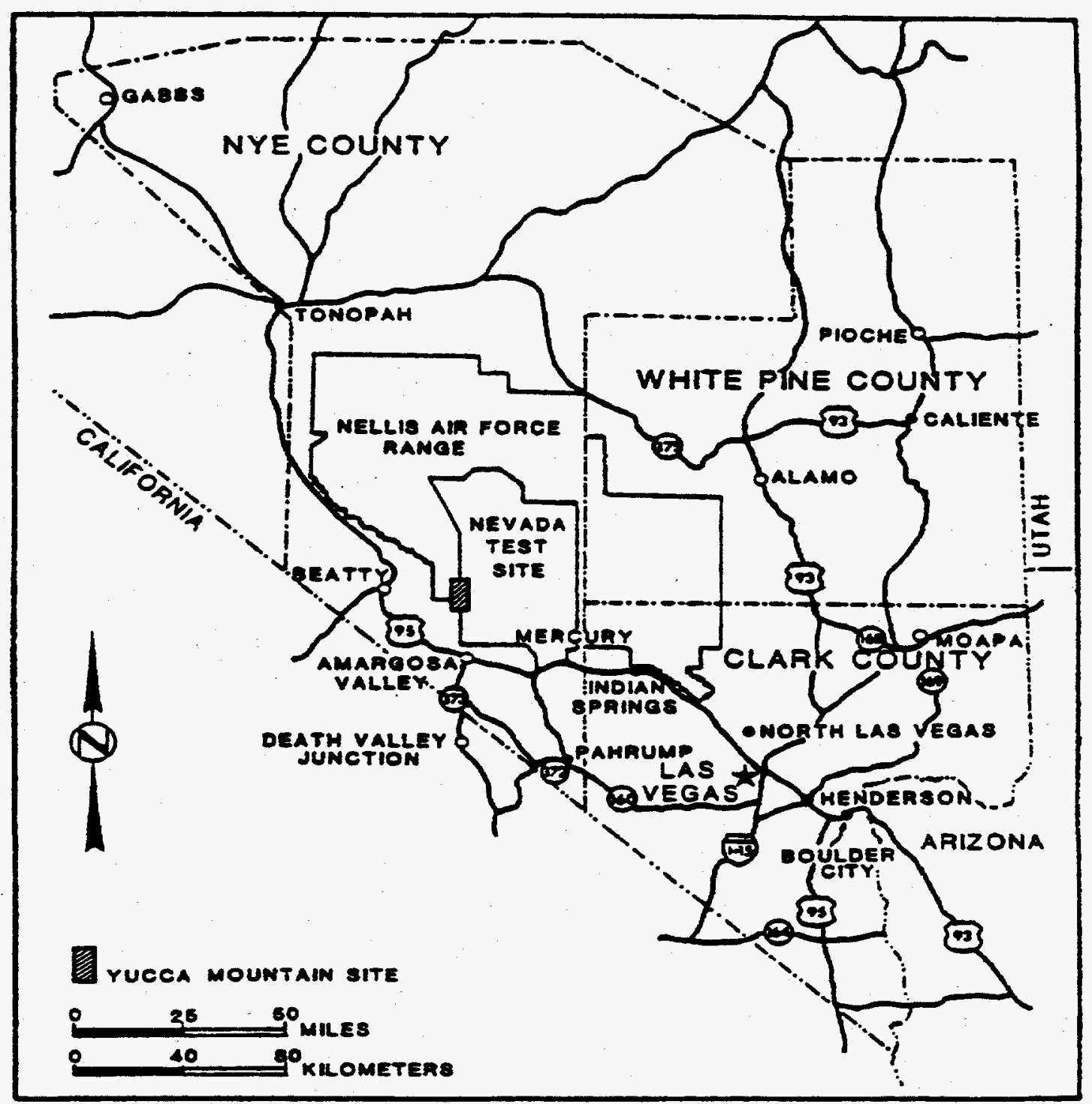

Figure 1. Location map of Yucca Mountain (from Linderfelt, 1987). 
Studies on fracture flow in the unsaturated zone at Yucca Mountain have generally assumed negligible resistance to flow at the fracture-matrix interface and have shown that any liquid water moving down the fractures will be quickly imbibed into the porous matrix (Foltz et al., 1993; Wang et al., 1993; Martinez et al., 1992: Zimmerman and Bodvarsson, 1990; Peters and Klavetter, 1988; Kilbury et al.. 1986; Wang and Narasimhan, 1985). However, the presence of a thin skin of low permeability material on the fracture walls may significantly impede imbibition into the matrix. Under such conditions, fracture flow would travel deeper and could potentially reach the proposed repository horizon. This process has potentially been demonstrated by the presence of tritium and chlorine-36 deep in the unsaturated zone at Yucca Mountain (Fabryka-Martin, 1994). The fracture skin, or coating, may be formed by mineral precipitation as water evaporates from the matrix into the fractures, alteration of the matrix minerals, deposition of organic and inorganic matter carried downward with infiltrating water, or the presence of rock varnish, an iron- and manganese-rich coating (Nagy et al., 1991).

The purpose of this study is to quantify the effects of fracture coatings on the process of imbibition into a tuff matrix by conducting laboratory experiments and fracture surface analysis, and to use the numerical code TOUGH (Preuss, 1987) to predict travel depth of infiltrating water in the presence of fracture coatings.

Chapter 2 discusses previous work on imbibition in fractured rocks. Chapter 3 discusses the experimental procedures used, and includes the laboratory analysis, scanning electron microscope analysis, and the conceptual model for the numerical simulation. Results from these analyses and their discussion are addressed in Chapter 4. Chapter 5 summarizes the conclusions of this work. 


\section{CHAPTER 2: STUDIES OF IMBIBITION IN FRACTURED ROCKS}

Studies on fracture flow in the unsaturated zone at Yucca Mountain have generally assumed negligible resistance to flow at the fracture-matrix interface and have shown that any liquid water moving down the fractures will be quickly imbibed into the porous matrix (Foltz et al.. 1993; Wang et al., 1993; Martinez et al., 1992; Zimmerman and Bodvarsson, 1990; Peters and Klavetter, 1988; Kilbury et al., 1986; Wang and Narasimhan. 1985). At Yucca Mountain, the most abundant fracture coatings are silica polymorphs, zeolites, and manganese-oxides, with lesser amounts of smectite, calcite and ferrous-oxides (Carlos et al., 1991). Fractures at Yucca Mountain are generally coated to some extent at all depths down to and below the water table (Thoma et al., 1992).

Capillary forces from the matrix acting on the mobile liquid water in the fractures start the process of imbibition. A convenient measure of the property of imbibition is the sorptivity (Philip, 1957). Sorptivity is controlled by the hydraulic properties of the matrix and its initial and final water contents. It is a measure of the capacity of the porous media to absorb liquid by capillarity (Philip, 1957). For horizontal infiltration from a fracture, the cumulative infiltration, I $(t)$, can be shown to be related to time $(\mathrm{t})$ through the sorptivity:

$$
I(t)=S\left(\theta_{i}, \theta_{f}\right) t^{1 / 2}
$$

where $\mathrm{S}\left(\theta_{\mathrm{i}}, \theta_{\mathrm{f}}\right)$ is the sorptivity $\left(\mathrm{L} / \mathrm{T}^{1 / 2}\right), \theta_{\mathrm{i}}$ and $\theta_{\mathrm{f}}$ are the initial and final water contents, respectively.

The sorptivity represents the influence of both capillary gradients and hydraulic conductivity during the transient flow process (Hillel, 1982). Measurement of sorptivity to characterize soils has long been in practice (Walker and Chong, 1986), but use of the sorptivity approximation to estimate infiltration in fracture-matrix systems is relatively recent (Zimmerman et al., 1993; Foltz et al., 1993; Humphrey et al., 1993; Rasmussen and Evans, 1993; Wang et al., 1993). Rasmussen and Evans (1993) measured infiltration into Apache Leap tuff matrix and analyzed the infiltration using the vertical equivalent of equation (1). They reported an average sorptivity value of $6.8 \times 10^{-2}$ $\mathrm{cm} / \mathrm{s}^{1 / 2}$. Foltz et al. (1993) used sorptivity to characterize imbibition in a fracture-matrix interface of Timber Mountain tuff. They showed that a plot of distance of the wetting front from the fracture versus $\mathrm{t}^{1 / 2}$ to be linear and calculated a sorptivity value of $7.4 \times 10^{-2} \mathrm{~cm} / \mathrm{s}^{1 / 2}$. Humphrey et al. (1993) conducted imbibition experiments on core samples of non- to moderately-welded ash-flow tuffs with porosity ranging from 9.4 to 53.3 percent and reported sorptivity values of $9 \times 10^{-4}$ to $193 \times 10^{-4}$ $\mathrm{cm} / \mathrm{s}^{1 / 2}$. More recently, Flint et al. (1994) conducted imbibition experiments on welded tuff from Yucca Mountain cores at various saturations and report a sorptivity value of $2.2 \times 10^{-3} \mathrm{~cm} / \mathrm{s}^{1 / 2}$ at dry initial saturation.

Equation (1) assumes a homogeneous porous material and is generally a good approximation for uncoated fracture surfaces, but the presence of fracture coatings makes the medium inhomogeneous. Figure 2 shows the expected effects of coatings on imbibition showing reduced imbibition when a coating of low permeability material lines the fracture.

Moench (1984) was the first to consider the effect of a low permeability fracture skin on the movement of water between fractures and rock matrix in a groundwater reservoir. Thoma et al. 

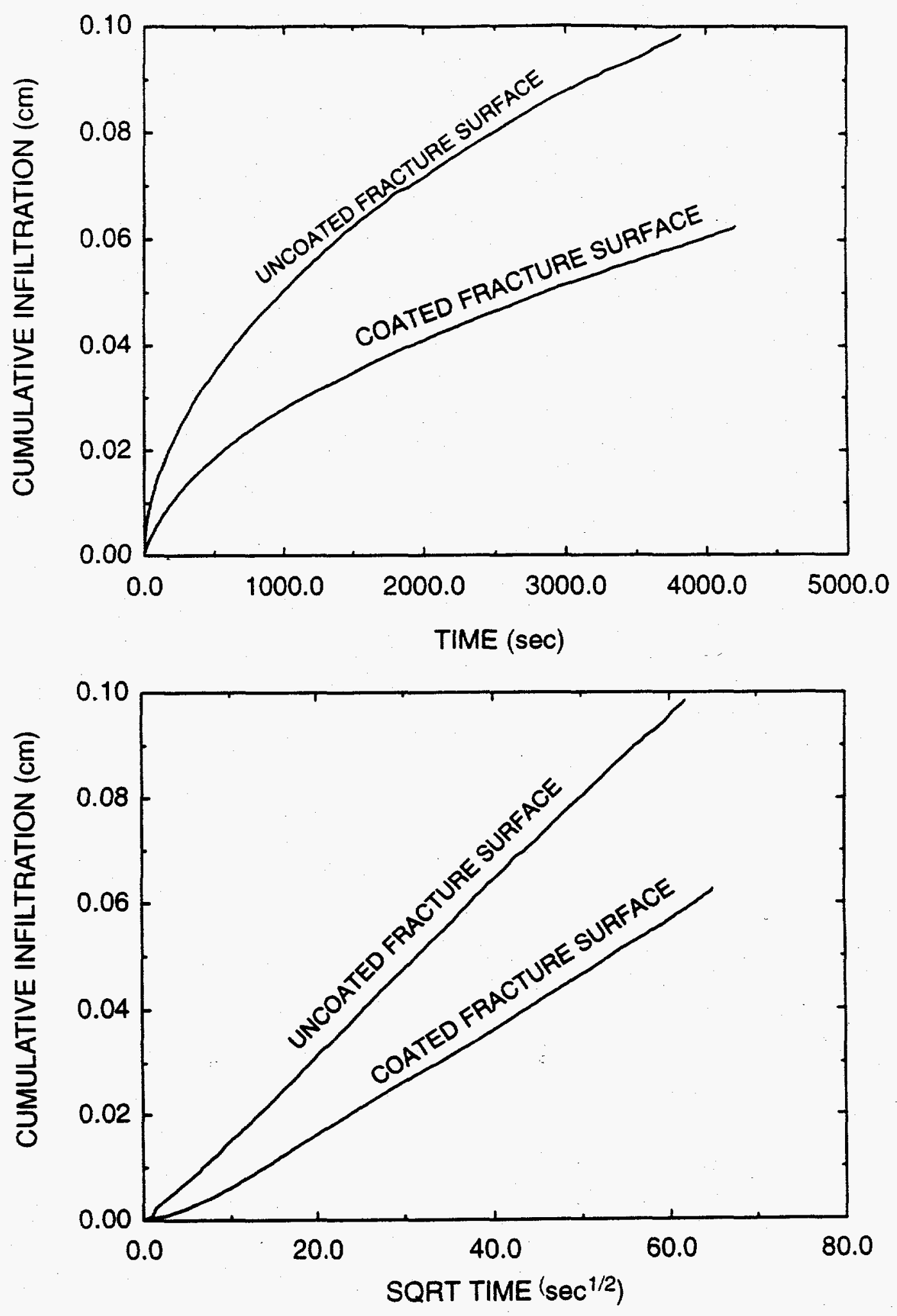

Figure 2. Experimental imbibiton versus time and square root time showing lower imbibition and lower sorptivity across a coated surface. 
(1992) considered the effect of fracture coatings on water imbibition into unsaturated matrix. They derived a quadratic equation for the volumetric uptake $(V)$ of water as a function of time across a coated fracture surface as:

$$
\begin{aligned}
& \text { where } \quad B=\frac{n_{2}^{2} A r_{2}^{2} L_{1}}{4 \tau_{2}^{2} k_{1}}-2 A n_{1} L_{1} \\
& C=\frac{n_{2}^{2} A_{2}^{2} r_{2} L_{1}^{2} \tau_{1}^{2}}{r_{1} T_{2}^{2}}-\frac{n_{2}^{2} A^{2} r_{2}^{2} L_{1}^{2} n_{1}}{4 \tau_{2}^{2} k_{1}}+A^{2} n_{1}^{2} L_{1}^{2)} \\
& D=\frac{n_{2}^{2} A^{2} r_{2} \sigma \cos \beta}{2 \mu \tau_{2}^{2}} \\
& \beta=\text { contact angle } \\
& \sigma=\text { surface tension of water } \\
& \mu=\text { dynamic viscosity } \\
& A=\text { cross-sectional area of imbibition } \\
& \mathrm{N}=\text { porosity } \\
& \tau=\text { tortuosity } \\
& L_{1}, L_{2}=\text { thickness of coating and rock matrix, respectively, and subscripts } 1 \text { and } \\
& 2 \text { represent the coating and rock matrix, respectively. }
\end{aligned}
$$

Equation (2) mathematically relates the volumetric uptake $\mathrm{V}$ of a liquid into an initially dry porous matrix across a coating that has a permeability $K_{1}$, thickness $L_{1}$, single representative pore size $r_{1}$, tortuosity $\tau_{1}$, and porosity $n_{1}$ as a function of time. For low permeability coatings, the model described by (2) could be fit to experimental data with good accuracy. However, the large number of parameters needed to characterize the volumetric uptake makes (2) difficult to apply.

Thoma et al. (1992) also conducted imbibition experiments on both glass beads and samples of Tiva Canyon and Paintbrush tuff. Glass beads were coated such that very low permeability fracture coatings could be tested. The coated bead experiments displayed the quadratic imbibition predicted by (2), while the tuff samples tended to show fairly linear $t^{1 / 2}$ behavior. In one tuff sample, (from Thoma et al., 1992) imbibition across the mineralized face was dramatically inhibited when compared to the non-mineralized face. They conclude that fracture coating permeability can have a significant and profound effect on imbibition.

Numerical models of fracture flow at Yucca Mountain can generally be divided into two major groups: equivalent porous media models (EPM) and discrete fracture models. The EPM models, such as developed by Peters and Klavetter (1988) and Martinez et al. (1992), are convenient from a computational standpoint, however, the role of fracture coatings cannot be assessed, as both the fractures and the matrix are modeled as a single, homogeneous element. 


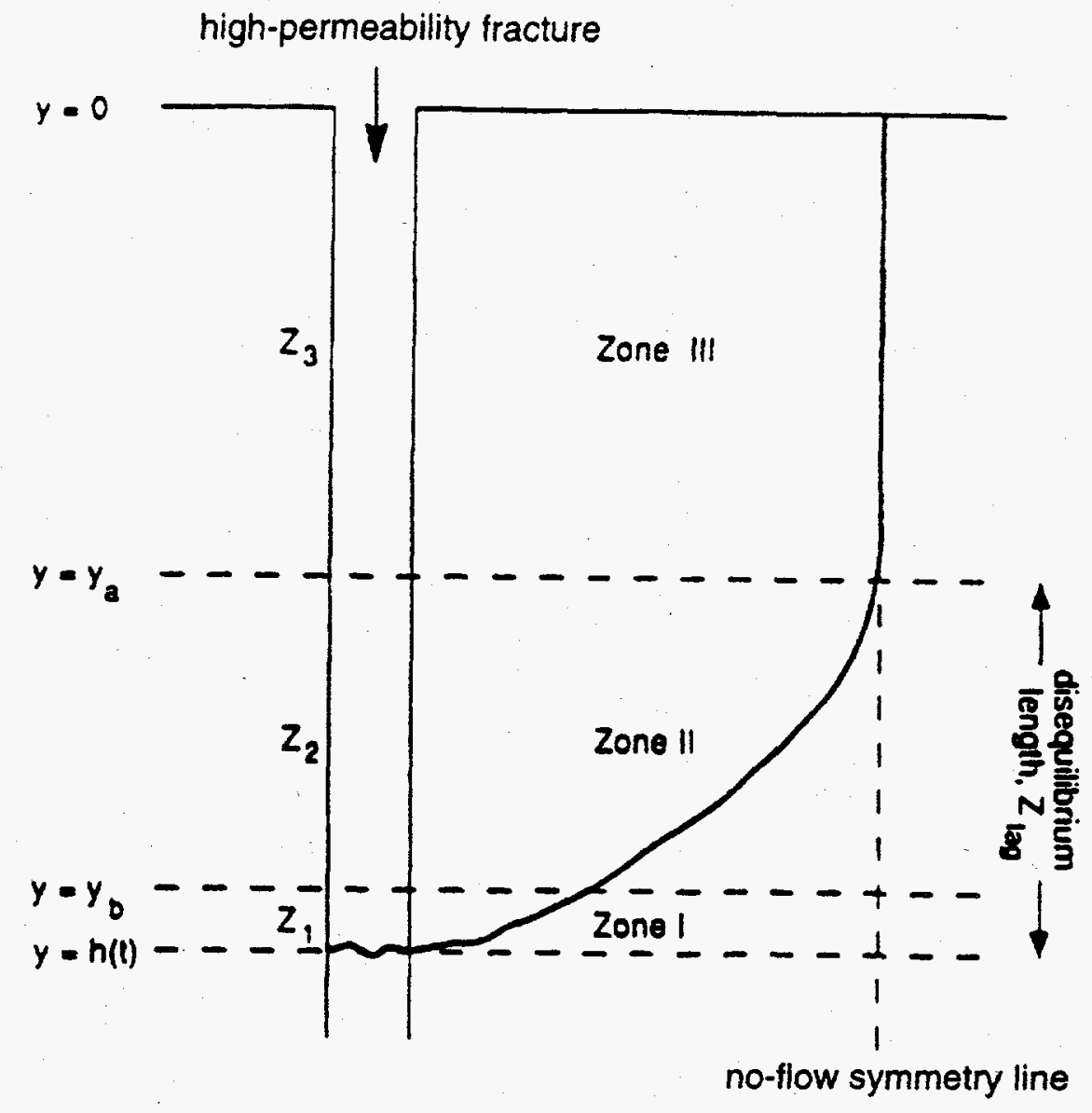

Figure 3. Three zones in the tuff matrix corresponding to three flow periods. From Nitao and Buscheck (1991).

To cover these limitations, Nitao and Buscheck (1991) modeled flow in a fracture, and from the fracture to the matrix by considering a two-dimensional, unsaturated, discrete, fracture system. The fracture is treated as a permeable vertical, one-dimensional porous medium. Their analysis considered only half of the system and assumed that compared to capillary forces, gravity-driven flow is negligible within the matrix. They also assumed that the matrix properties were homogeneous and isotropic, and the initial matrix saturation was uniform. They considered a periodic system of fractures spaced a constant distance apart. The midpoint of this constant distance is the lateral boundary for a single fracture under consideration. This lateral boundary is considered a no-flow boundary. Using the above boundary conditions, they derived equations to calculate fracture-matrix interaction times, wetting front travel times and distances in a fracture for flow periods.

Physically, they divided the flow in a fracture into three flow periods (Figure 3). During Period I, the front travels rapidly and the flow is weakly influenced by matrix imbibition; during Period II, imbibition retards fracture flow, and the fracture flow velocity continually decreases proportional 
to $\mathrm{t}^{-1 / 2}$; and during Period III, flow starts in the matrix adjacent to the fracture entrance and completely saturates the matrix until it reaches the lateral no-flow boundary. Within the matrix these three periods correspond to three zones: Zone I, which is adjacent to the wetting front, consists of horizons whose cumulative imbibition flux is less than the specific fracture flow volume. In Zone II, above Zone I, the cumulative imbibition flux is greater than fracture flow volume, but the imbibition front has not reached the lateral no-flow boundary; and in Zone III, which is directly above Zone II, the cumulative flux approximately equals the saturated or nearly saturated portion of the matrix. Flow Period I occurs when only Zone I is present; Period II begins when Zone II first forms and ends with the appearance of Zone III; and Period III starts and continues after this point (Figure 3).

Nitao and Buscheck (1991) found considerable retardation of fracture flow due to matrix imbition. They utilized a numerical model (V-TOUGH, an enhanced version of TOUGH [Preuss, 1987]) to model the flow in a fracture. The fracture was represented by a vertical column of grid blocks, with a fracture aperture of $100 \mu \mathrm{m}$ and porosity of 90 percent. They assumed a ponded boundary condition at the fracture which was maintained at constant head. The saturation behind the front in the fracture was observed to remain at least 95 percent within flow Period II and even higher percentage in flow Period III. They showed that the results of this numerical study compared well with their analytical model. They concluded that in simulations for repository performance, the porous nonwelded units require smaller fracture-matrix interaction times (less than one second), resulting in almost immediate slow down of fracture flow by high matrix sorption fluxes. But the matrix imbibition in the welded units is too small by itself, to prevent fracture flow over long distances under high flux conditions.

In summary, while there have been numerous studies dealing with unsaturated fracture flow at Yucca Mountain, the significance of fracture coatings on deep infiltration has only begun to be recognized. In the following chapters, experimental and numerical results are presented which clearly show the importance of fracture coatings and their role in the development of fast pathways. 


\section{CHAPTER 3: METHODS OF ANALYSES}

\section{LABORATORY ANALYSIS}

To investigate the role of fracture coatings on sorptivity. laboratory imbibition experiments were conducted on a variety of fractured volcanic tuffs including the Tiva Canyon and Topopah Spring tuffs from Yucca Mountain. Samples were collected from surface outcrops of Tiva Canyon and Topopah Spring tuffs on the western side of Yucca Mountain (Figure 4). The fracture coatings consisted of desert varnish with little or no carbonate coatings visible and may not be representative of coatings at depth. Experiments were first conducted on a natural fracture surface. The samples were then fractured to expose a fresh fracture surface and a second imbibition experiment was conducted. Samples were oven-dried at the start and between each experiment. The samples were very brittle and when fractured with a hammer opened up nearly smooth surfaces. It is assumed that because the samples are densely welded and brittle, breaking the samples with a hammer did not affect their porosity and permeability.

Sorptivity can be measured relatively quickly and accurately and, by definition, does not need to attain a steady-state condition for its measurement. For the laboratory experiments, a sorptivity cell (Thoma et al., 1992; Flint, 1992; Peters et al., 1988) was modified and is shown in Figure 5. Samples were drilled, fitted with an expansion bolt and connected to the underside of an electronic balance with a thin copper rod. Sample sizes were roughly $50 \mathrm{~cm}^{3}$. A large container of water resting on a laboratory jack was slowly brought into contact with the sample surface from underneath. The use of a large container of water eliminated the effects of time-varying supply head encountered by Thoma et al. (1992). As the water surface touched the sample there was an immediate weight gain caused by the surface tension of water. This was verified by running an experiment with a steel body in place of the rock samples that displayed no imbibition. The plot of this experiment (Figure 6) clearly shows a sharp increase in weight in the first one or two seconds and then immediately stabilizes. This sharp initial increase observed for all the samples was omitted from the final data plots.

The samples were sealed around the edges with silicone sealant to prevent evaporation from the sample. The electronic balance was connected to a computer which was programmed to record the weight change of the sample due to imbibed water once every second. The weight gain, which is in grams, was converted to centimeters of water imbibed by dividing the weight gain by the surface area of the sample surface and density of water. The sample surface was traced on paper and the area was measured with a planimeter, calibrated to a known area. The cumulative infiltration was plotted against the square root of time, generally yielding a straight line, the slope of which is the sorptivity. Since sorptivity dominates over gravity during early time, experiments were run for a short duration (generally one hour). Since capillary forces dominate in these fine-grained tuffs, the effects of gravity are assumed to be negligible during the experimental time period. The experiments were conducted on oven-dried samples and the sorptivities measured are therefore maximum sorptivities. After oven drying, the samples were allowed to equilibrate with ambient atmosphere for two hours. 


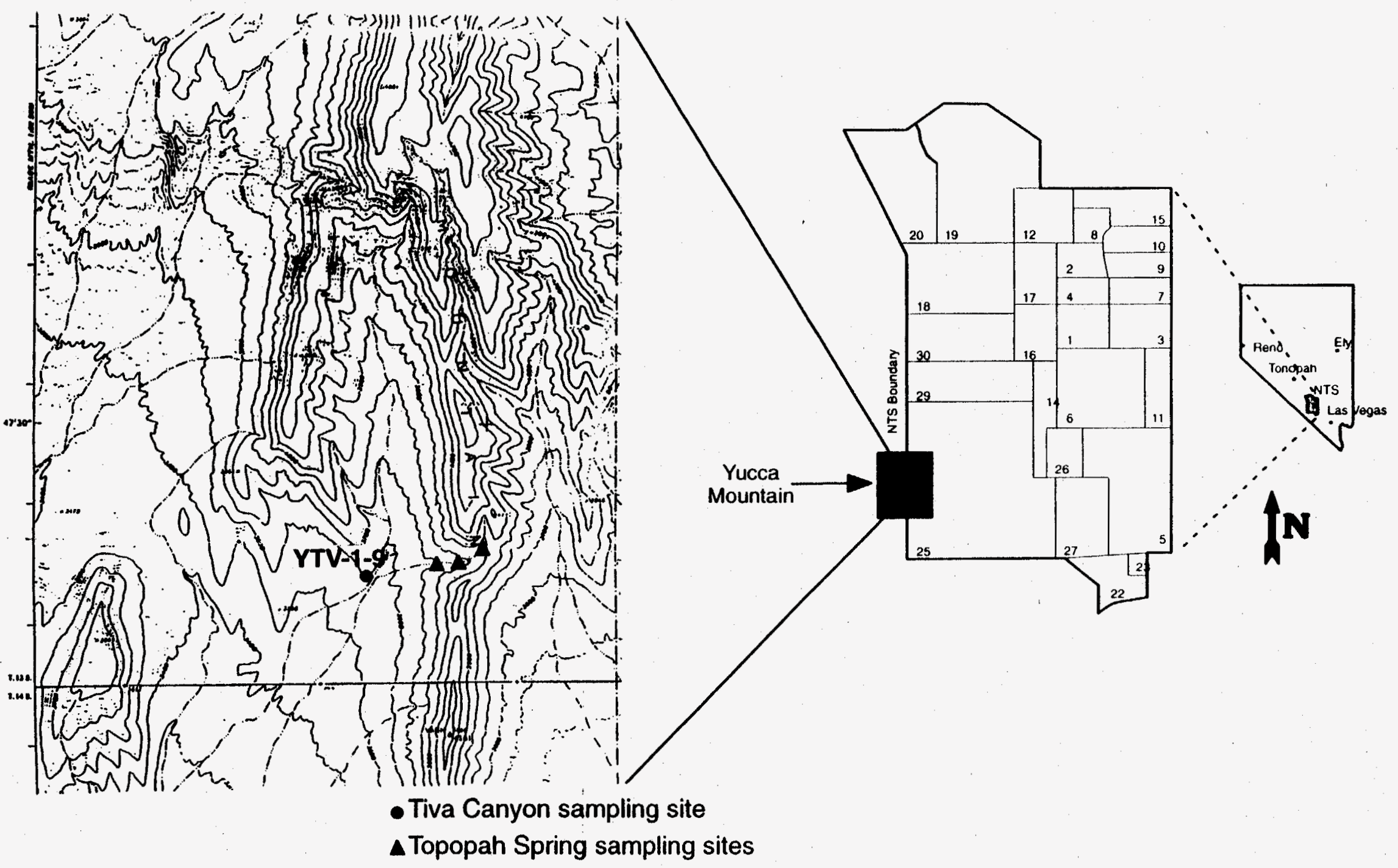

Figure 4. Regional map of Yucca Mountain showing locations where Tiva Canyon Tuff and Topopah Spring Tuff samples were collected. 


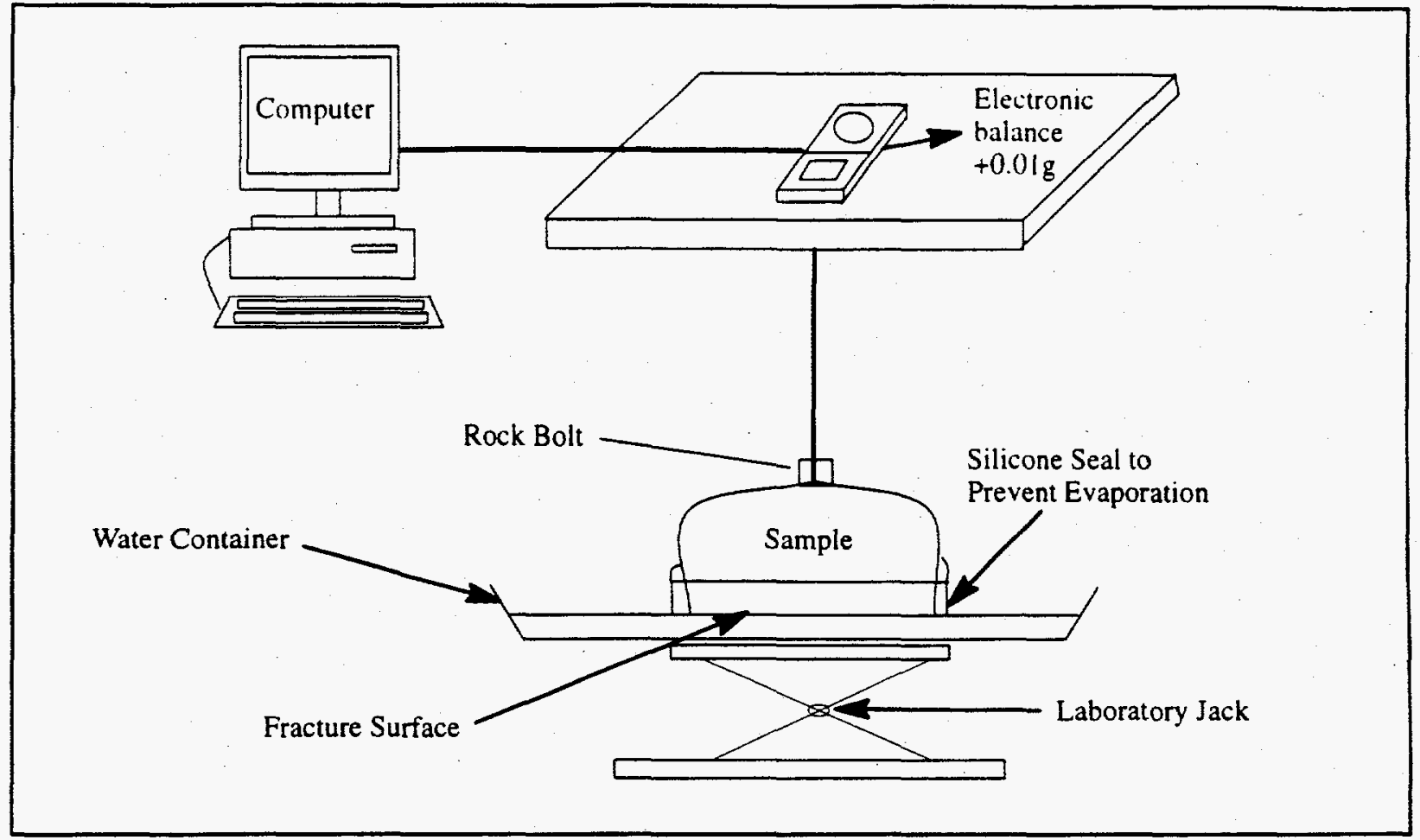

Figure 5. Experimental design used to measure sorptivity. The sample size is enlarged to show detail.

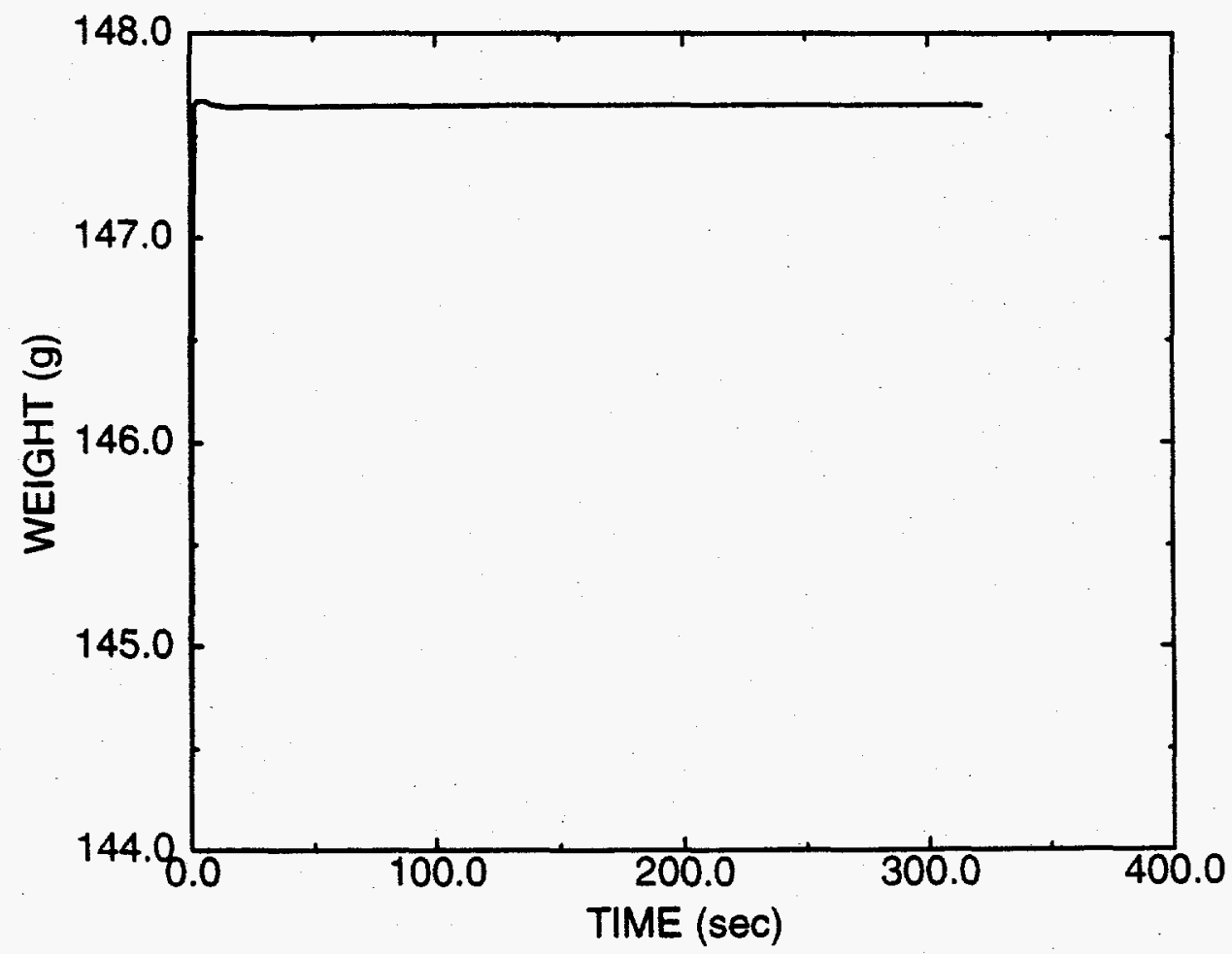

Figure 6. Imbibition experiment with a steel body which displayed no imbibition. The initial weight gain is due to surface tension. 
Due to the low permeability of the samples, uptake of moisture from the atmosphere during this cool down period was assumed to be negligible.

\section{STATISTICAL METHODS}

Statistical analysis was performed on the measured sorptivities of both Tiva Canyon and Topopah Spring tuffs. The statistical analytical methods used were the paired t-test, Completely Randomized Design (CRD), Randomized Complete Block Design (RCBD), $2 \times 2$ Factorial Design in CRD, and 2×2 Split-plot in CRD (Fernandez, 1991). The statistical package SAS was used in analyzing the data.

A t-test helps in finding the effect of coating on sorptivity, i.e., whether coating is significantly reducing sorptivity or not. A CRD analysis is useful when the samples are homogenous and aids in finding what treatment is causing the differences in experimental sorptivity. RCBD analysis is useful in finding whether the samples are homogenous or not. It also indicates if the samples are not uniform, then differences in sorptivity could be due to sample variation. A factorial design helps in finding whether coating has different effects on different rock types. A split-plot design is a specialized design for a factorial experiment (Fernandez, 1991). It emphasizes one factor over the other.

\section{FRACTURE SURFACE ANALYSIS}

Scanning electron microscope (SEM) analysis was used to investigate whether the coatings on the samples are chemically different, to compare the pore structure between coated and uncoated fracture surfaces and to compare the observed pore structure to retention data from other researchers.

SEM analysis is a useful technique in the examination and analysis of microstructural characteristics of solid objects (Goldstein et al., 1981). In practice, the area to be examined is irradiated with a finely focused electron beam, which can either be static or swept in a rastor across the surface (Goldstein et al., 1981). Many types of signals are produced when an electron beam strikes a solid specimen; the most important of these are the secondary electrons which are used to form the SEM images (Goldstein et al., 1981).

The instrument used in the present study is a JEOL 100 fitted with an Energy Dispersive Spectrometer (EDS) located at the Nevada Bureau of Mines \& Geology. In the EDS method, a lithium-diffused silicon semiconductor is used as a radiation detector. When an electron beam irradiates the specimen under study it emits $\mathrm{x}$-ray signals. These $\mathrm{x}$-ray signals are collected by the $\mathrm{Si}$ ( $\mathrm{Li}$ ) detector. As each $\mathrm{x}$-ray signal is absorbed, the detector emits a photoelectron. This photoelectron travels in the detector scattering inelastically, and in the process creates electron-hole pairs. These electron-hole pairs are in turn carried away by the applied bias to form a charge pulse. With the help of a charge-sensitive preamplifier, the charge pulse is converted to a voltage pulse. The voltage pulse is further amplified, shaped, and passed to a multi-channel analyzer, where the pulses are sorted by voltage and displayed (Goldstein et al., 1981). 


\section{NUMERICAL SIMULATIONS}

To determine the impact of fracture coatings on transport at Yucca Mountain, the numerical model TOUGH (Preuss, 1987) was utilized along with experimental sorptivity data. The TOUGH code (Transport of Unsaturated Groundwater and Heat) is a multi-dimensional model developed by Lawrence Berkeley Laboratories (Pruess, 1987). The code can simulate coupled transport of water, vapor, air, and heat in porous or fractured media.

A two-dimensional model was developed with the fracture vertically oriented. Two different fracture widths were modeled. The flow in the fracture is vertical due to gravity primarily, and horizontal due to capillary pressure from the matrix. The domain assumed that the fracture as filled with high permeability material with high porosity to simulate an open fracture. Both Tiva Canyon and Topopah Spring tuff units with different permeabilities were modeled each to a depth of $100 \mathrm{~m}$ and a lateral thickness of $50 \mathrm{~cm}$. Both the fracture and the matrix were discretized into variably spaced grids. The permeabilities of both Tiva Canyon and Topopah Spring tuff were determined by fitting numerical simulations of horizontal imbibition with those measured in the laboratory. Half of the fracture and only one side of the fracture-matrix system was actually modeled (Figure 7). The

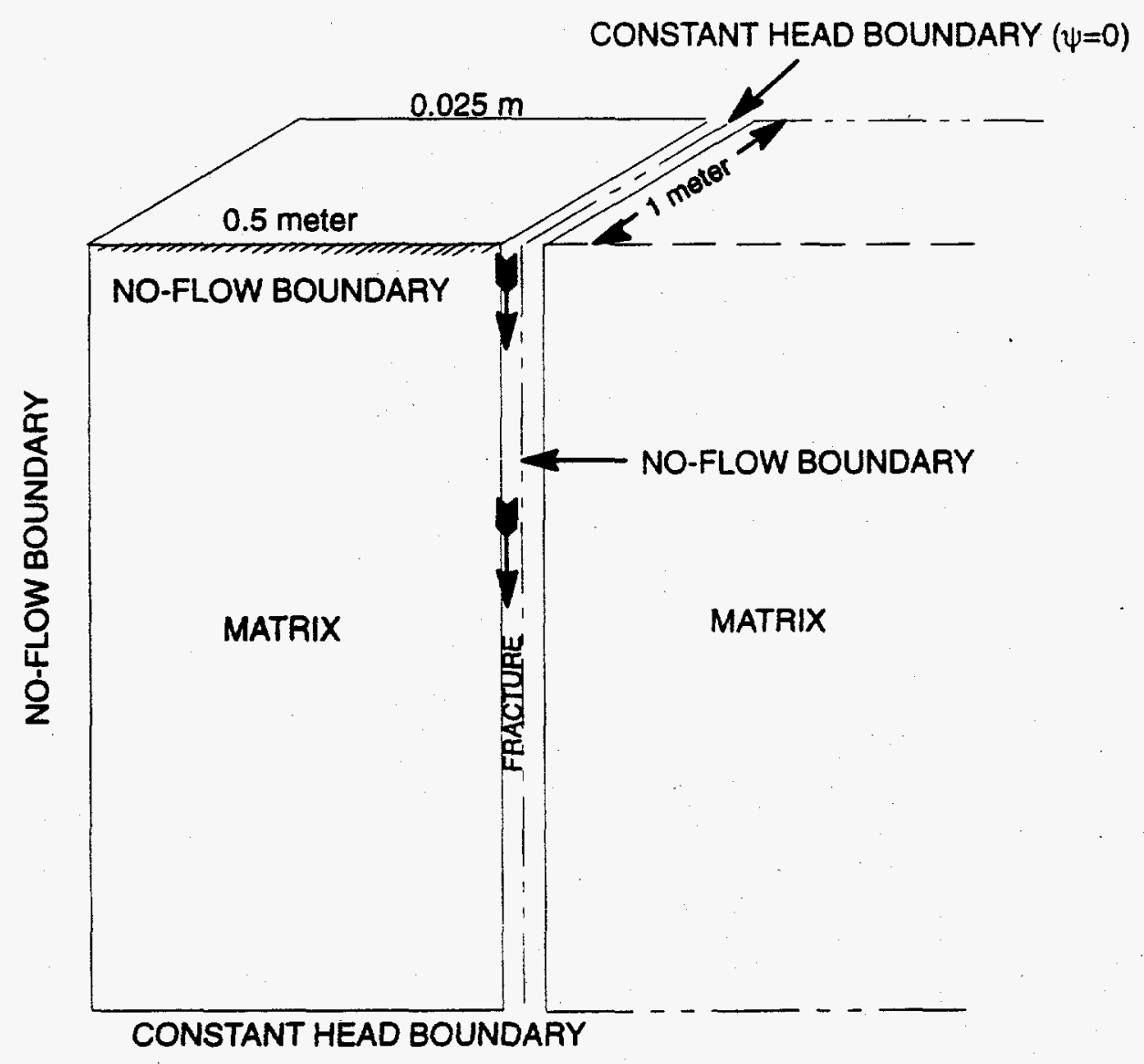

Figure 7. Conceptual model showing various boundary conditions. The simulated domain was divided in half and only the left side of the fracture-matrix system was modeled. 
fracture saturated permeabilities used in the model were $1.2 \times 10^{-11}$ and $3.0 \times 10^{-12} \mathrm{~m}^{2}$, corresponding to fracture apertures of 12 microns and 6 microns, respectively, using a parallel plate analogue. These relatively narrow fractures were used to avoid numerical instability problems caused by large differences in the fracture and matrix saturated permeabilities. The water enters only the fracture and is not allowed to infiltrate vertically into the matrix. The top boundary of the fracture is taken to be a constant head boundary at atmospheric pressure. The top and the lateral boundaries of the matrix $50 \mathrm{~cm}$ from the fracture were modeled as no-flow boundaries. The matrix boundary next to the fracture is a capillary pressure boundary. The bottom for both fracture and matrix was assumed to be a constant head boundary. 


\section{CHAPTER 4: RESULTS AND DISCUSSION}

\section{LABORATORY RESULTS}

Experiments were conducted on nine Tiva Canyon samples (denoted YTV\#1 to 9). Sorptivity estimates calculated from the imbibition experiments for the coated surfaces ranged from $3.39 \times 10^{-4}$ to $9.75 \times 10^{-4} \mathrm{~cm} / \mathrm{s}^{1 / 2}$ and for uncoated surfaces from $2.6 \times 10^{-4}$ to $7.5 \times 10^{-4} \mathrm{~cm} / \mathrm{s}^{1 / 2}$ (Table 1). As can be seen from the correlation coefficients $\left(R^{2}\right)$, the use of equation (1) appears justified in all cases. Of all the samples, YTV\#6 showed the largest difference in sorptivity values between the coated and uncoated surfaces and YTV\#8 showed the least difference.

TABLE 1. CALCULATED SORPTIVITY VALUES FOR TIVA CANYON TUFF SAMPLES.

$R$-squared values refer to the goodness of fit of the regression line to equation 1.

\begin{tabular}{lllll}
\hline \hline & \multicolumn{2}{c}{ Calculated sorptivity $\left(\mathrm{cm} / \mathrm{s}^{1 / 2}\right)$} & \multicolumn{2}{c}{$\mathrm{R}^{2}$} \\
SAMPLE & Coated & Uncoated & Coated & Uncoated \\
\hline YTV\#1 & $4.97 \times 10^{-4}$ & $3.37 \times 10^{-4}$ & 0.99746 & 0.99668 \\
YTV\#2 & $4.15 \times 10^{-4}$ & $3.76 \times 10^{-4}$ & 0.99757 & 0.99891 \\
YTV\#3 & $6.58 \times 10^{-4}$ & $4.75 \times 10^{-4}$ & 0.99884 & 0.99802 \\
YTV\#4 & $3.66 \times 10^{-4}$ & $7.5 \times 10^{-4}$ & 0.99725 & 0.99463 \\
YTV\#5 & $7.95 \times 10^{-4}$ & $5.23 \times 10^{-4}$ & 0.99762 & 0.99869 \\
YTV\#6 & $9.75 \times 10^{-4}$ & $3.29 \times 10^{-4}$ & 0.99933 & 0.99043 \\
YTV\#7 & $4.35 \times 10^{-4}$ & $5.2310^{-4}$ & 0.99814 & 0.99489 \\
YTV\#8 & $5.23 \times 10^{-4}$ & $4.9 \times 10^{-4}$ & 0.99933 & 0.99876 \\
YTV\#9 & $3.39 \times 10^{-4}$ & $2.67 \times 10^{-4}$ & 0.99789 & 0.99870 \\
\hline \hline
\end{tabular}

Figure 8 shows the calculated sorptivity versus sample number for all Tiva Canyon samples. It is evident from the figure that seven out of nine samples (YTV\#1,2,3,5,6,8, and 9) show higher sorptivity values for the coated surfaces compared to the uncoated surfaces. The only two samples (YTV\#4 and 7) showed response believed typical of low permeability coatings. There are two possible explanations for the contrary behavior: 1) fracture orientation relative to an anisotropic pore structure resulting in an anisotropic sorptivity and 2) an increase in the porosity and permeability across the coated surface due to weathering along the grain boundaries.

Anisotropy in volcanic tuff permeability is caused by the preferred orientation of microcracks, elliptical pores and mineral grains which occur due to uplift or cooling, and compaction of gas-filled cavities of extrusive rocks such as tuff solidify (Martin et al., 1992). Interestingly, for most of the sorptivity measurements on Tiva Canyon samples, the coated surface that was measured was parallel to the visible bedding and so the imbibition across this surface is perpendicular to this bedding, while the imbibition direction for freshly opened surfaces for these samples was parallel to bedding. Figure 9 shows the tabulated sorptivities for the six samples in which the imbibition across the coated 
surface was perpendicular to bedding. Contrary to expectation, five out of six samples showed the highest sorptivity perpendicular to the bedding. The only exception is YTV\#4, in which the imbibition across the uncoated fracture surface was higher than for the coated fracture surface. Visibly, this sample had a thicker fracture coating than the other six samples and which may explain the result.

Figure 10 shows sorptivity values of samples YTV\#2 and YTV\#6. For both of these samples, the imbibition direction for both the coated and uncoated surfaces was parallel to bedding and the sorptivity values are constantly higher for the coated surfaces. Here, differences between the imbibition are solely a function of the fracture coating. The imbibition direction for sample YTV\#7 for both the coated and uncoated surfaces was perpendicular to bedding, and the uncoated surface shows higher sorptivity. There is no clear explanation for this result at this time, however, the limited sample number reduces the significance of the result.

One would expect the imbibition parallel to the bedding to be larger in magnitude than that perpendicular to the bedding direction. However, most of the coated imbibition experiments were conducted perpendicular to the bedding, yet still yielded higher infiltration rates, suggesting anisotropy was not the cause of the differences. It is likely that for these tuffs, being densely welded with a porosity of 5 to 15 percent, weathering along the grain boundaries may increase the near-surface porosity of the tuff and result in higher sorptivity across the coated fracture. The fracture coatings may also be too thin to significantly reduce imbibition.

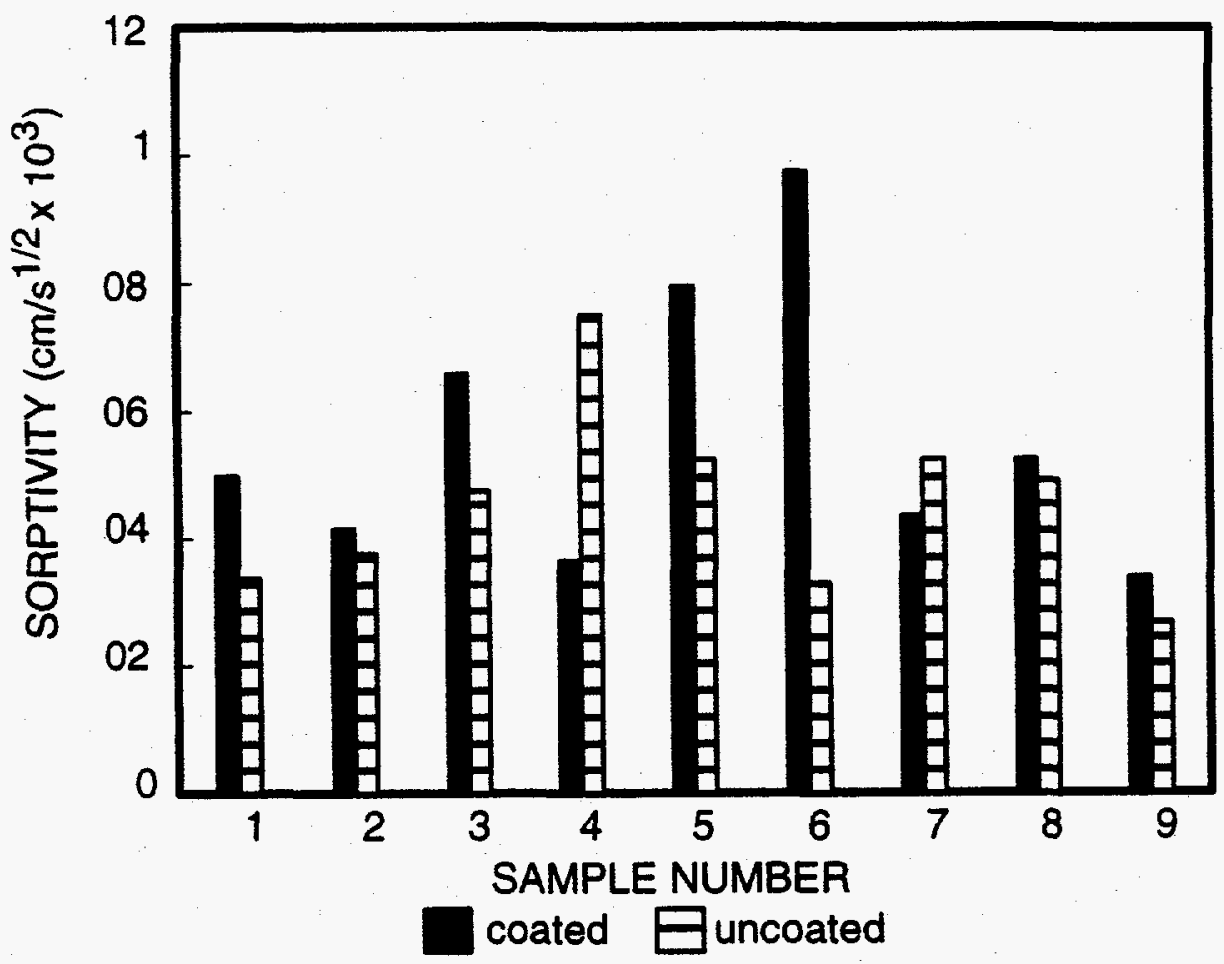

Figure 8. Coated versus uncoated sorptivities for all Tiva Canyon samples investigated. 


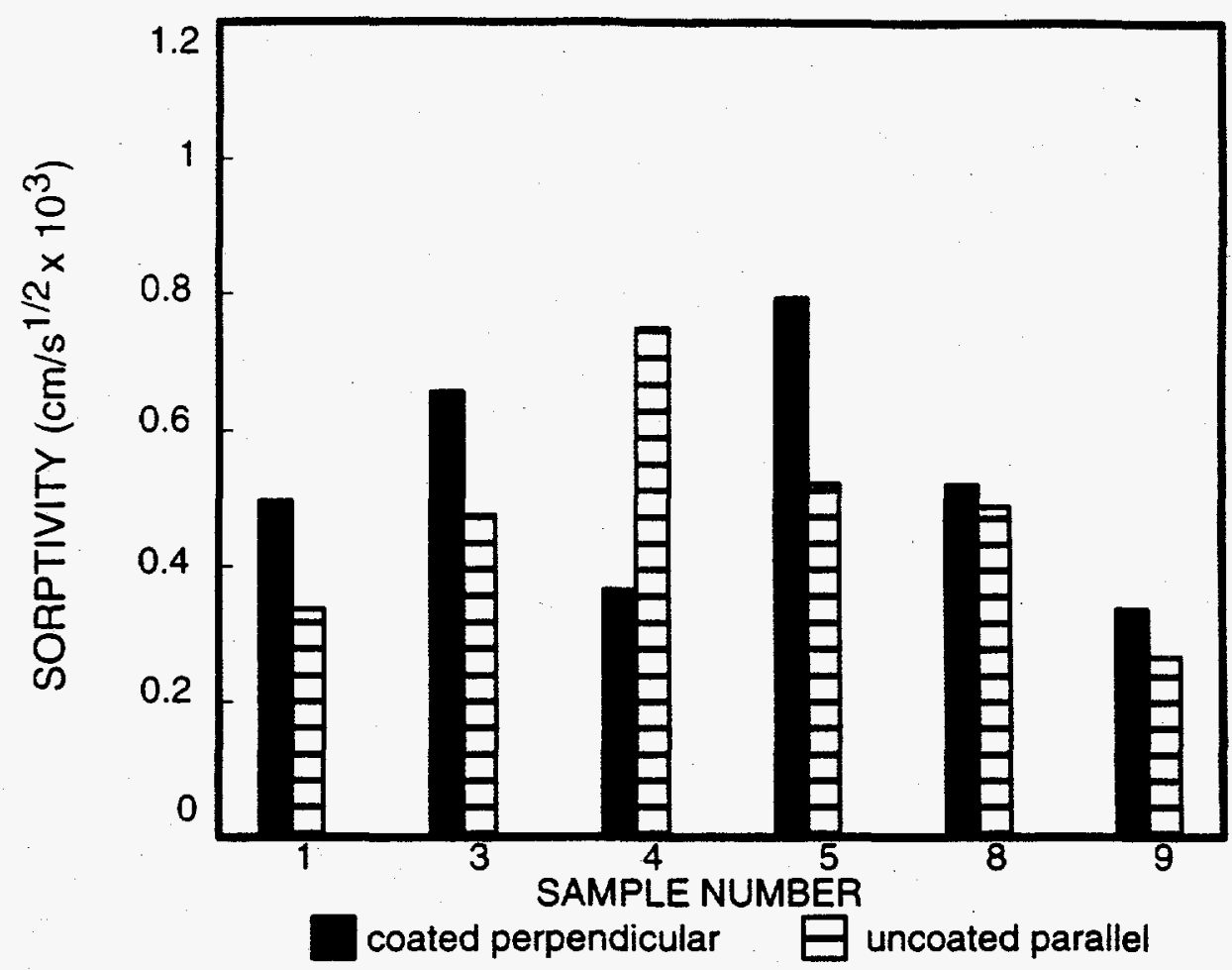

Figure 9. Comparison of sorptivities showing the effects of bedding orientation. On five out of six samples, imbibition was higher across coated surfaces in which the bedding orientation was perpendicular to the imbibition direction, as compared to the uncoated surface in which the bedding was parallel to the imbibition direction. Higher imbibition perpendicular to the bedding orientation is not consistent with the anticipated anisotropy.

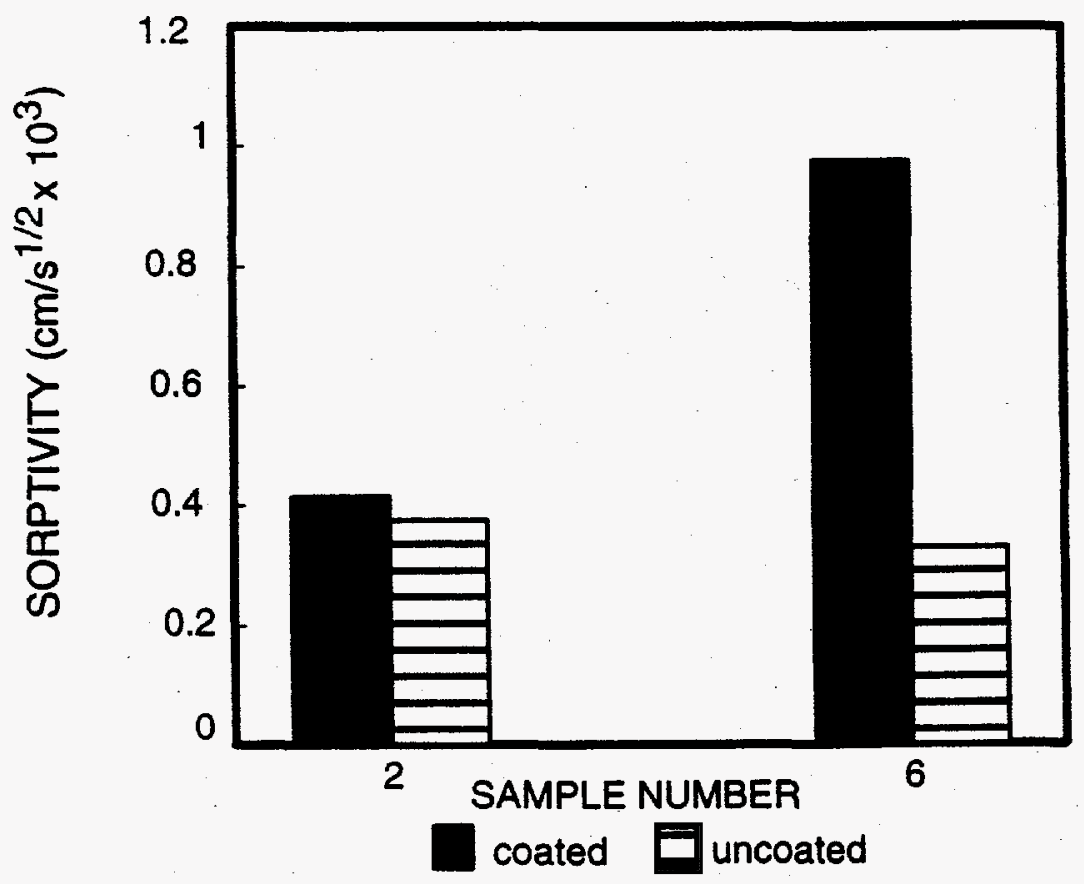

Figure 10. Comparison of sorptivities for samples in which both imbibition directions (coated and uncoated) were parallel to the bedding direction. 


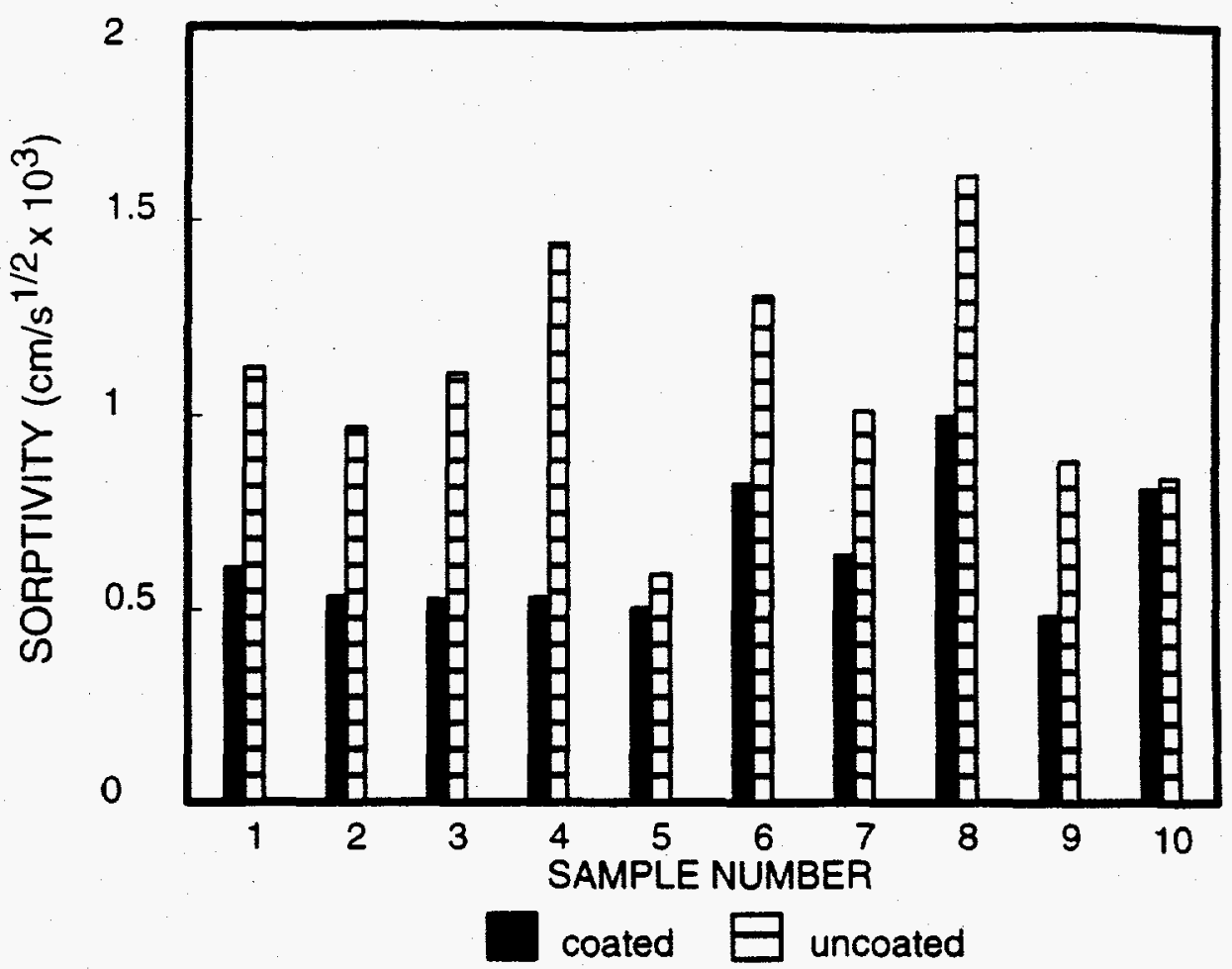

Figure 11. Coated versus uncoated sorptivities for all Topopah Spring samples investigated.

Imbibition experiments were next conducted on ten Topopah Spring samples (denoted YTP\#1 to 10), with all experimental imbibition directions carefully selected to be parallel to bedding. These samples were collected from the lithophysal unit of Topopah Spring tuff and so the compaction direction and the imbibition direction were easy to identify. Results of analysis of these samples were contrary to Tiva Canyon results, i.e., they are in accordance with the hypothesis that a coating can significantly reduce the imbibition. As seen in Figure 11, the uncoated fracture surfaces have higher sorptivities than the coated fracture surfaces for all the samples. The difference in sorptivities between the coated and uncoated fracture surfaces is nearly double except for sample YTP\#5 and YTP\#10. Visibly, the coating on these samples was thicker than the coating on Tiva Canyon samples. In general, sorptivities for Topopah Spring samples, which range from $5 \times 10^{-4}$ to $16 \times 10^{-4} \mathrm{~cm} / \mathrm{s}^{1 / 2}$, are higher than sorptivities of Tiva Canyon samples. This may be due to higher average porosity and permeability in Topopah Spring tuff, which is $14 \%$ and $3.9 \times 10^{-18} \mathrm{~m}^{2}$, respectively. For the Tiva Canyon tuff, average porosity and permeability is $12 \%$ and $2.4 \times 10^{-18} \mathrm{~m}^{2}$ (Rulon et al., 1986). 
TABLE 2. CALCULATED SORPTIVITY VALUES FOR TOPOPAH SPRING TUFF SAMPLES.

$R$-squared values refer to the goodness of fit of the regression line to equation 1.

\begin{tabular}{lllll}
\hline \hline & \multicolumn{2}{c}{ Calculated sorptivity $\left(\mathrm{cm} / \mathrm{s}^{1 / 2}\right)$} & \multicolumn{2}{c}{$\mathrm{R}^{2}$} \\
SAMPLE & Coated & Uncoated & Coated & Uncoated \\
\hline YTP\#I & $6.08 \times 10^{-4}$ & $11.2 \times 10^{-4}$ & 0.99596 & 0.99934 \\
YTP\#2 & $5.32 \times 10^{-4}$ & $9.69 \times 10^{-4}$ & 0.99409 & 0.99973 \\
YTP\#3 & $5.25 \times 10^{-4}$ & $11.08 \times 10^{-4}$ & 0.99604 & 0.99946 \\
YTP\#4 & $5.3 \times 10^{-4}$ & $14.37 \times 10^{-4}$ & 0.99449 & 0.99922 \\
YTP\#5 & $5.03 \times 10^{-4}$ & $5.9 \times 10^{-4}$ & 0.99488 & 0.99940 \\
YTP\#6 & $8.25 \times 10^{-4}$ & $13.05 \times 10^{-4}$ & 0.99745 & 0.99885 \\
YTP\#7 & $6.4 \times 10^{-4}$ & $10.14 \times 10^{-4}$ & 0.99180 & 0.99842 \\
YTP\#8 & $10.02 \times 10^{-4}$ & $16.18 \times 10^{-4}$ & 0.99958 & 0.99990 \\
YTP\#9 & $4.84 \times 10^{-4}$ & $8.85 \times 10^{-4}$ & 0.98952 & 0.99862 \\
YTP\#10 & $8.13 \times 10^{-4}$ & $8.44 \times 10^{-4}$ & 0.99738 & 0.99900 \\
\hline \hline
\end{tabular}

\section{STATISTICAL RESULTS}

\section{Tiva Canyon Tuff}

A paired t-test was used to test the significance of the coating on the Tiva Canyon samples using the difference in sorptivity values for the coated and uncoated surfaces. Any effects of anisotropy and sample-to-sample variation were initially ignored. Results of this test indicate that the coating was not significant. The probability $(\mathrm{P})$ value is 0.2970 . A probability value of less than 0.05 indicates that the treatment (coated vs. uncoated) makes a significant impact on the data.

To determine if there is any sample-to-sample variation or if anisotropy was a factor, a Randomized Complete Block Design (RCBD) was used with the samples as blocks. Three different treatments were tested: imbibition into a) uncoated parallel to bedding b) coated parallel to bedding and c) coated perpendicular to bedding. These treatments are chosen because Tiva Canyon samples fell into these three groups only. The term "blocks" means that each sample set (coated and uncoated) is taken as a group. Units within a block are considered as uniform so that the observed differences within a block are due to treatments (Fernandez, 1991). Blocking helps in maximizing variability among blocks and minimizing variability within blocks. Sample YTV\#7 was not used in this design because of lack of similar samples. It is also assumed that the samples are completely randomized. Here again, neither the blocks $(P<0.5856)$ nor the treatments $(P<0.2632)$ were found to be significant. In other words, blocks or groups do not vary significantly, the samples are more or less uniform. Similarly, treatments taken to test the effectiveness of anisotropy on imbibition did indicate significant differences between sorptivity data. The reason for this behavior, as can be seen in Figure 8 , is that while there is significant variation in sorptivity between coated and uncoated surfaces for a given sample, when average sorptivities are calculated, there is little difference between samples. So when taken as a whole, there is no statistically significant variation. 
Since the blocks were not significant, block effect was removed and a simple Completely Randomized Design (CRD) was used with the same treatments. This was done to increase the error degrees of freedom and further test the significance of the treatments, which might have been obscured by the blocks in RCBD analysis. However, the results of this test also showed that treatments were not significant $(P<0.2672)$. This further confirmed that anisotropy was not the cause of higher sorptivities seen for coated fracture surfaces of Tiva Canyon samples.

Since YTV\#7 was not used for either RCBD or CRD analysis and since sample YTV\#4 is in accordance with the hypothesis due to thicker coating, the data of these two samples were removed and a paired t-test was used again to test whether the coating affects the sorptivity values. The coating's effect on sorptivity was then found to be significant at the $5 \%$ level $(P=0.05)$.

\section{Topopah Spring Tuff}

Paired t-test analysis was also used for Topopah Spring results to evaluate the difference in the sorptivity values for the coated and uncoated fracture surfaces. Sample-to-sample variation was ignored and since the imbibition direction for both coated and uncoated fracture surfaces was parallel to bedding, anisotropy was not a factor. Results of this test showed that the coating was significant in affecting sorptivity at the $1 \%$ level $(\mathrm{P}<0.001)$.

To determine if there was sample-to-sample variation among the Topopah Spring samples, RCBD analysis was used with samples as blocks and the two treatments were tested: (1) coated and (2) uncoated. The results of this test showed that the blocks were only significant at the $10 \%$ level $(\mathrm{p}<0.1021)$. However, coating was found to be highly significant $(\mathrm{P}<0.001)$. A simple CRD was used to check if the blocking had any effect on treatments. The results showed that the significance level of treatments did not improve; on the contrary, the significance level decreases, though very slightly (the $P$ value was 0.0017 as opposed to 0.0010 ). Blocks were therefore significant at the $10 \%$ level $(\mathbf{P}<0.1021)$ for Topopah Spring tuff. The reason for the significant blocks is that Topopah Spring samples were collected at three different locations, at different elevations, and the approximate distance between each sample site was about $300 \mathrm{~m}$, while the Tiva Canyon samples were all collected within a radius of $200 \mathrm{~m}$. The Topopah Spring samples therefore may reflect the differences in position within the unit, while the Tiva Canyon samples are likely to be from the same horizon within the unit.

To compare the differences in rock types of Tiva Canyon and Topopah Spring tuffs, and to test the effect of coating on each rock type, a $2 \times 2$ factorial design in the CRD was used. The treatments are: factor A: two lithology types, Tiva Canyon and Topopah Spring, and factor B: coated and uncoated effect. Again samples were chosen as blocks. Only two treatments were taken for factor $B$, because anisotropic treatments for Tiva Canyon were found not to be significant in earlier tests, and for Topopah Spring, anisotropy was not a factor at all. The results of this test showed that rock types were highly significant, i.e., Tiva Canyon and Topopah Spring tuffs were significantly different $(P<0.0001)$. The effect of coating was significant at the $5 \%$ level $(P<0.0220)$ and the interaction between rock type and coating was even more significant $(P<0.0007)$. This showed that the effect of coating was different for each rock type. 
A least square mean comparison test was also performed simultaneously (Table 3).

TABLE 3. LEAST SQUARED MEANS OF 2 X 2 FACTORIAL DESIGN AND THEIR P VALUES.

\begin{tabular}{llll}
\hline & \multicolumn{2}{l}{ Least Squared Means of two levels of rock types } & \\
Two levels of coating & Topopah Spring & Tiva Canyon & P value \\
\hline Coated & 0.00066422 & 0.00055589 & 0.3049 \\
Uncoated & 0.00111167 & 0.00045222 & 0.0001 \\
P value & 0.0001 & 0.3259 & \\
\hline \hline
\end{tabular}

Least square mean values from the above table showed that for the coated treatment, the effect of rock type was not significant $(\mathrm{P}<0.3049)$, i.e., there is no influence of rock type on coating. For uncoated treatment, the effect of rock type was highly significant $(P<0.0001)$. The uncoated fracture surfaces of both Tiva Canyon and Topopah Spring tuffs are entirely different and reflects the difference in porosity and permeability of the two units. Within the Topopah Spring there was significant difference $(P<0.0001)$ between coated and uncoated treatments, while within the Tiva Canyon, there was no significant difference $(P<0.3259)$ between coated and uncoated treatments, already demonstrated in earlier tests.

\section{SCANNING ELECTRON MICROSCOPE (SEM)}

Four coated and four uncoated Tiva Canyon samples (YTV\# 4,5,6, and 8) and an equal number of Topopah Spring samples (YTP\# 3,4,8, and 10) were analyzed SEM. Tiva Canyon sample YTV\#4 was selected because it showed lower sorptivity across the fracture coating. YTV\#6 was selected because it showed maximum difference in sorptivity between coated and uncoated surfaces. YTV\#5 was selected as a representative sample for the contrary behavior of Tiva Canyon. YTV\#8 was selected as it has the least difference in the sorptivity between coated and uncoated surfaces.

Similarly for the Topopah Spring samples, YTP\#4 was selected because it showed maximum difference in sorptivity between coated and uncoated surfaces. YTP\#8 was selected because it showed highest sorptivity for both the coated and uncoated surfaces. YTP\#3 was selected as a representative sample for apparent calcium-carbonate coated samples, and YTP\#10 was selected because of the least difference in the sorptivity between coated and uncoated surfaces.

SEM images were generally taken at $1000 x$, but some images were also taken at higher magnification. The $1000 x$ magnification was chosen to get a clear image of the micropore structure and at the same time to cover a large surface area. The surface structure of both Tiva Canyon and Topopah Spring tuffs were similar. Figure $12(\mathrm{a}, \mathrm{b})$ shows the uncoated surface of two Tiva Canyon and Topopah spring samples. Images of uncoated surfaces clearly showed porosity with pore width ranging from roughly 1 micron to 10 microns (Figure 12a). The depth extension of these pores could not be discerned from the images, however, the surfaces were irregular and jagged. In contrast, coated surfaces for both Tiva and Topopah Spring tuff were relatively smooth with interconnected cracks covering the surface (Figure 13a, b). 
a)

TIVA CANYON: UNCOATED SURTACE

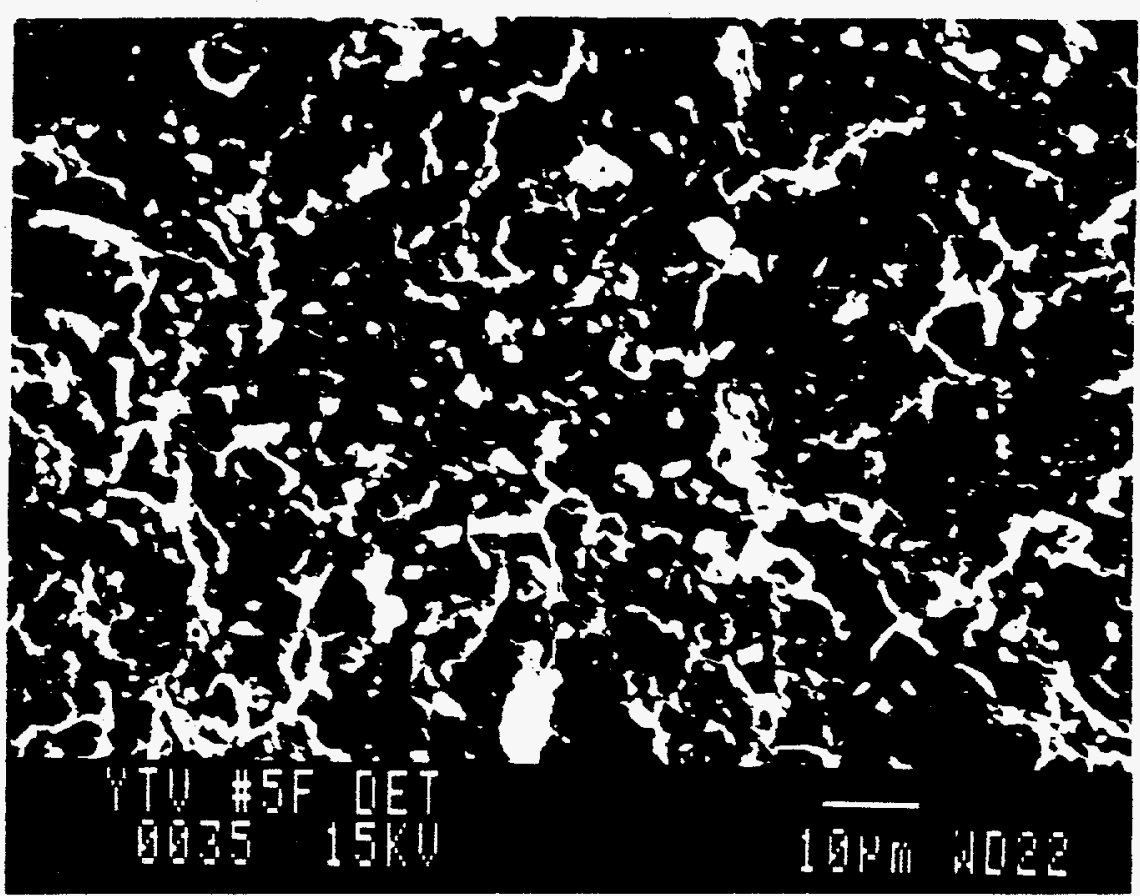

b)

TOPOPAH SPRING: UICOATED SUREACE

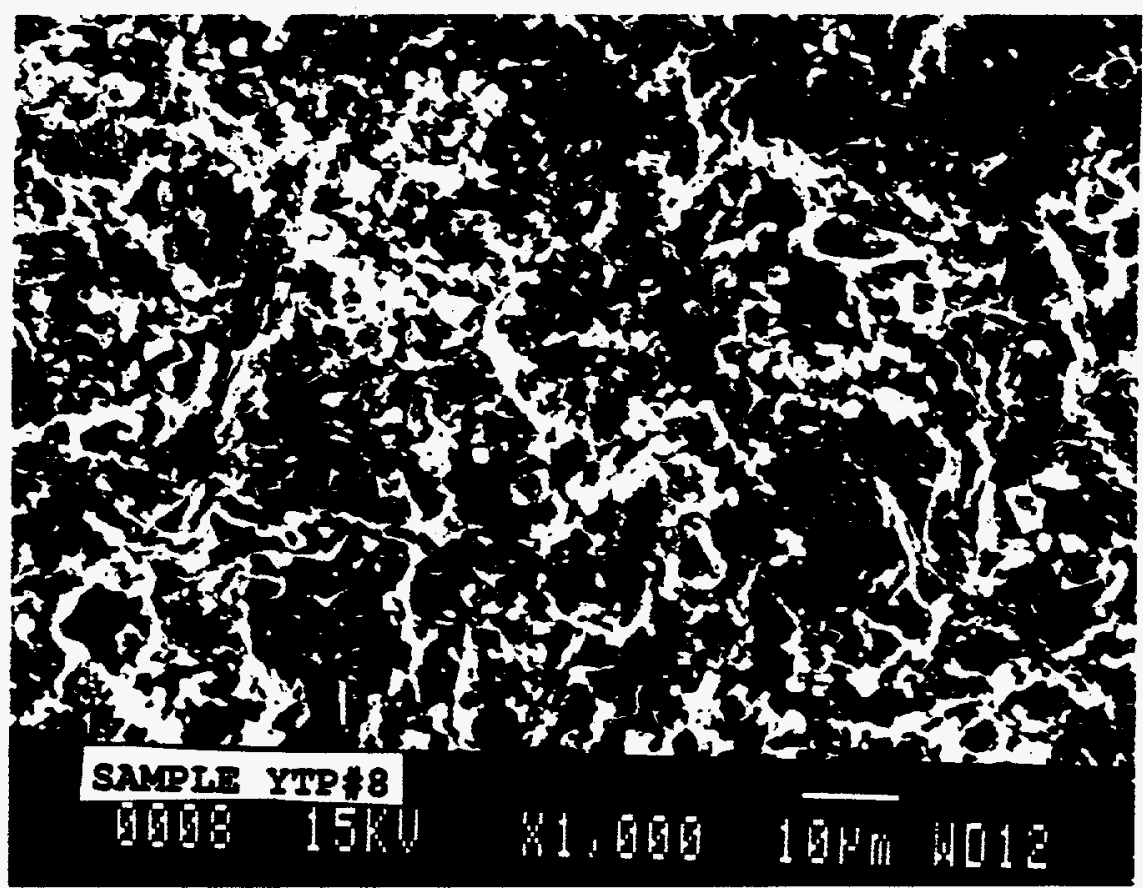

Figure 12. SEM images of uncoated fracture surfaces for Tiva Canyon (12a) and Topopah Spring tuff (12b). 
a)

TIVA CANYON: COATED SUREACE

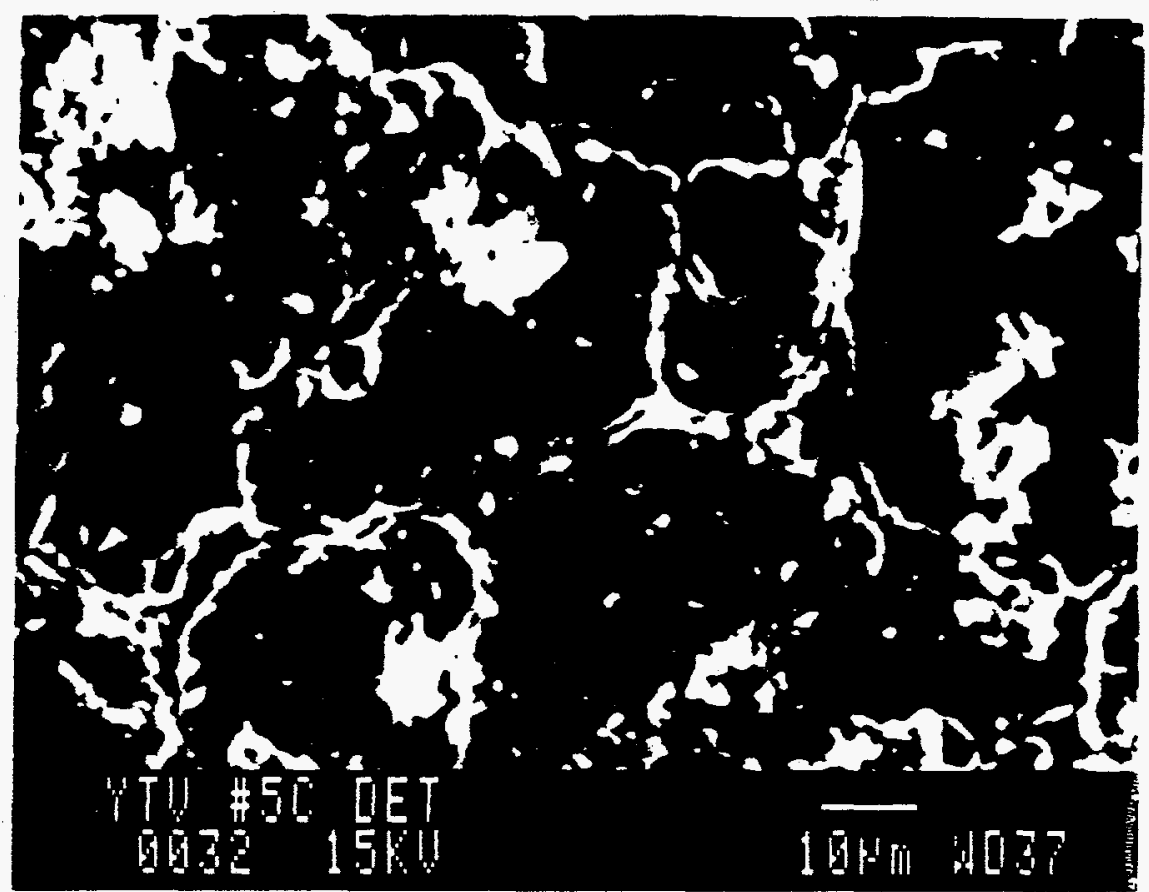

b)

TOPOPAB SPRING: COATED SURFACT

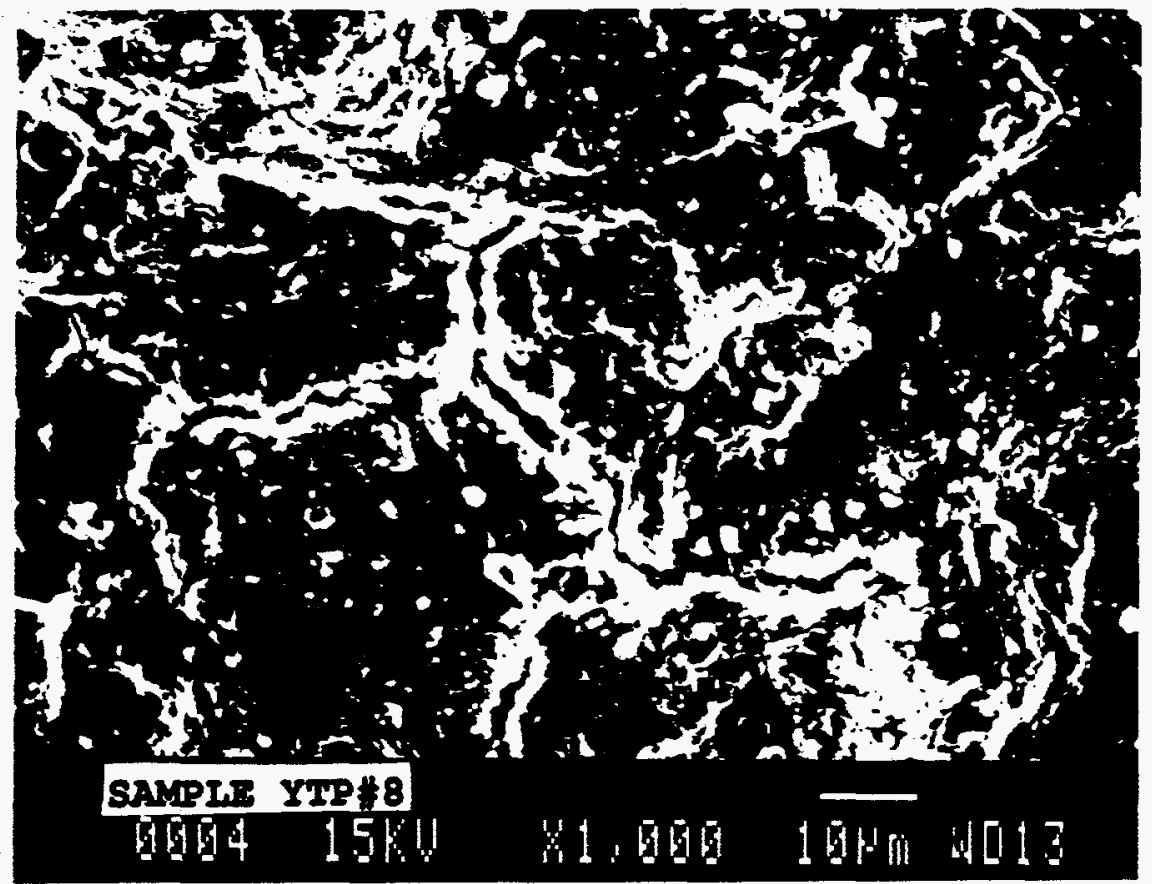

Figure 13. SEM images of coated surfaces of Tiva Canyon tuff (13a) and Topopah Spring tuff (13b). The coating is generally smooth, with abundant polygonal cracks.. 
Analysis of uncoated surfaces showed that the tuff material is made up of silica, potassium, aluminum and in minor quantities oxygen and sodium (Figure 14). Results of SEM analysis of coated surfaces for Tiva Canyon samples showed that the coating material is principally made up of iron and to a lesser extent calcium and magnesium (Figure 14). Only sample YTV\#4 showed manganese. These results are consistent with the fact that all the samples analyzed were collected from surface outcrops.

SEM analysis for Topopah Spring showed that the chemical composition of the coating material is similar to coatings on Tiva Canyon, however, the quantities of the same elements are higher in Topopah Spring, especially calcium and magnesium (Figure 15). Some of the coated samples of Topopah Spring have a visibly thick calcium carbonate coating. SEM analysis of YTP\#3, selected to represent samples with apparent calcium carbonate coating, showed large quantities of calcium (Figure 16), although the carbonate anion cannot be detected by SEM. Topopah Spring samples are also composed of silica, potassium, and aluminum and in minor quantities sodium and oxygen. SEM images for uncoated surfaces of Topopah Spring showed pore structure similar to Tiva Canyon uncoated surfaces (Figure 13). The coated surfaces of Topopah Spring were slightly thicker (Figure 13). The SEManalysis suggests that the reason for the lower sorptivities observed for coated sample surfaces as compared to uncoated sample surfaces for Topopah Spring samples was mainly the presence of calcium and magnesium. The higher sorptivities seen for uncoated surfaces of Topopah Spring samples compared to Tiva Canyon uncoated surfaces, however, were due principally to the higher permeability in the Topopah Spring (Rulon et al., 1986).

\section{NUMERICAL RESULTS}

Four different matrix permeabilities were modeled (Topopah Spring tuff: coated and uncoated, and Tiva Canyon tuff: coated and uncoated). These permeabilities were calculated from the average experimental sorptivity data by running TOUGH numerical simulations in a configuration similar to the experimental design. Imbibition distance versus the square root of time was plotted from the simulations. The permeability was varied until the slope of infiltration versus $t^{1 / 2}$ line matched the average experimental sorptivity data for all four scenarios (Figures 18, 19, 20 and 21). The average experimental sorptivity values used to estimate permeabilities for Topopah Spring tuff are $6.64 \times 10^{-4}$ and $11.11 \times 10^{-4} \mathrm{~cm} / \mathrm{s}^{1 / 2}$, respectively, for coated and uncoated fracture surfaces. The average experimental sorptivity values used to estimate permeabilities for Tiva Canyon tuff, coated and uncoated, are $5.56 \times 10^{-4}$ and $4.5 \times 10^{-4} \mathrm{~cm} / \mathrm{s}^{1 / 2}$, respectively.

\section{Model Input Data}

The matrix unsaturated data excluding permeability used in the model were the van Genuchten hydraulic property parameters $\left(\alpha, \lambda, S_{l}, S_{r}\right)$ given by Klavetter and Peters (1986), where $S_{1}$ and $S_{r}$ are liquid saturation and residual saturation and $\alpha$ and $\lambda$ are curve fit parameters. The fracture retention curve was assumed to be similar to that of coarse sand, to simulate a highly permeable and transmission region. The initial saturation in the fracture was assumed to be 3.6 percent. From the retention for the fracture, the initial capillary pressure is roughly $1 \mathrm{MPa}$ (Figure 21). The fracture relative permeability assumed to be linearly related to its saturation for simplicity. Figure 22 shows 

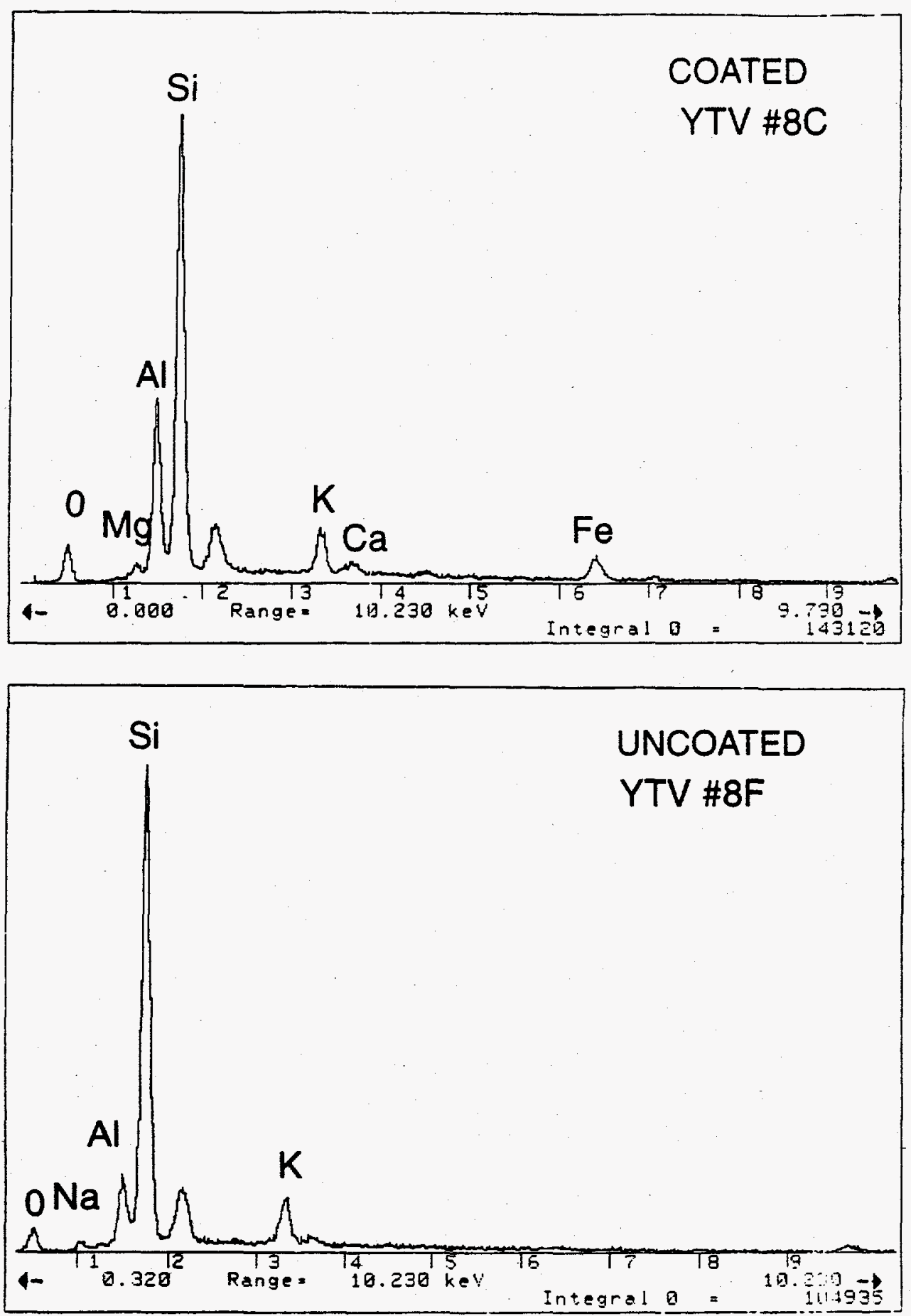

Figure 14. Energy Dispersive X-Ray Spectrum for coated and uncoated samples of Tiva Canyon tuff. 

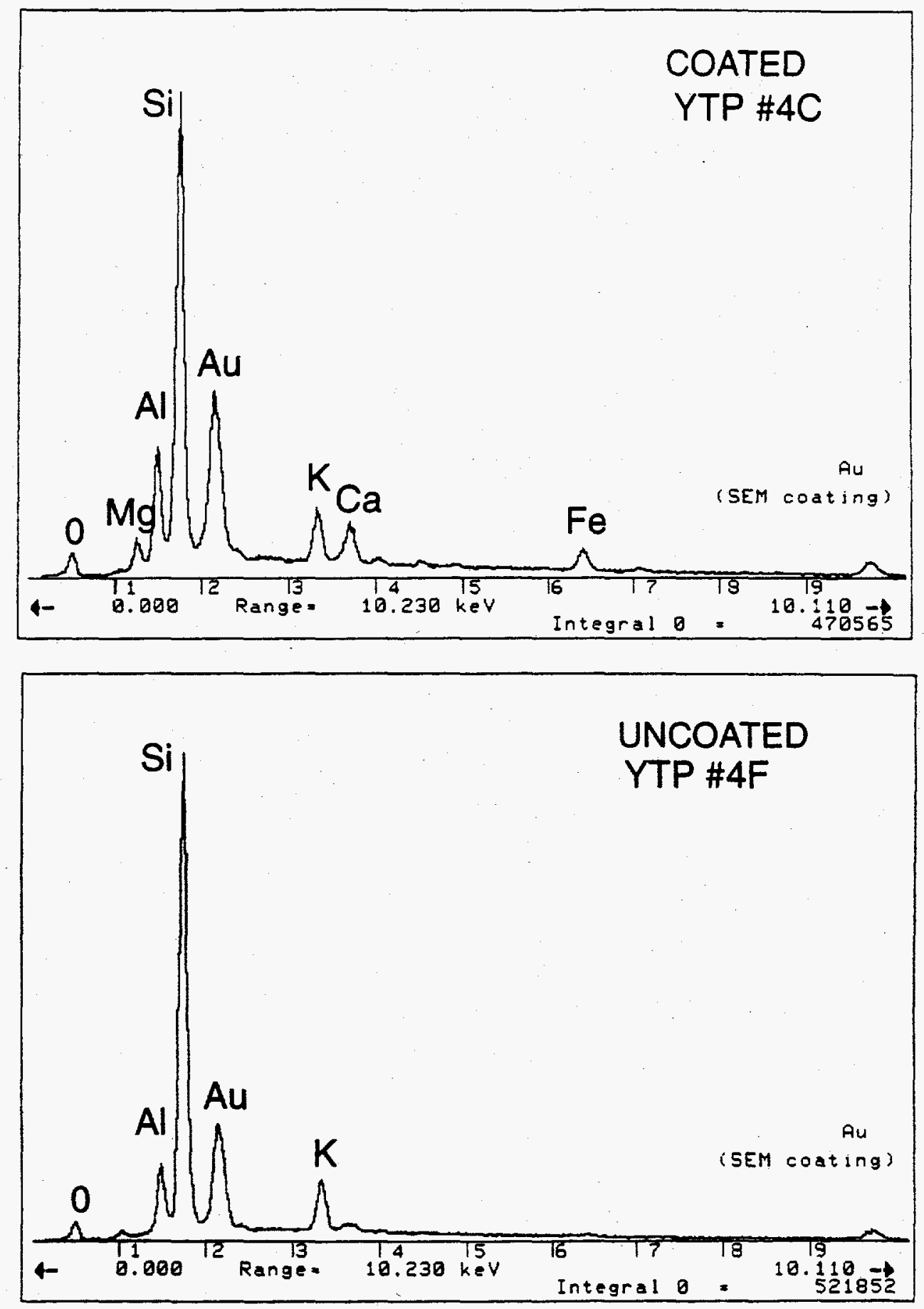

Figure 15. Energy Dispersive X-Ray Spectrum for coated and uncoated samples of Topopah Spring tuff. 


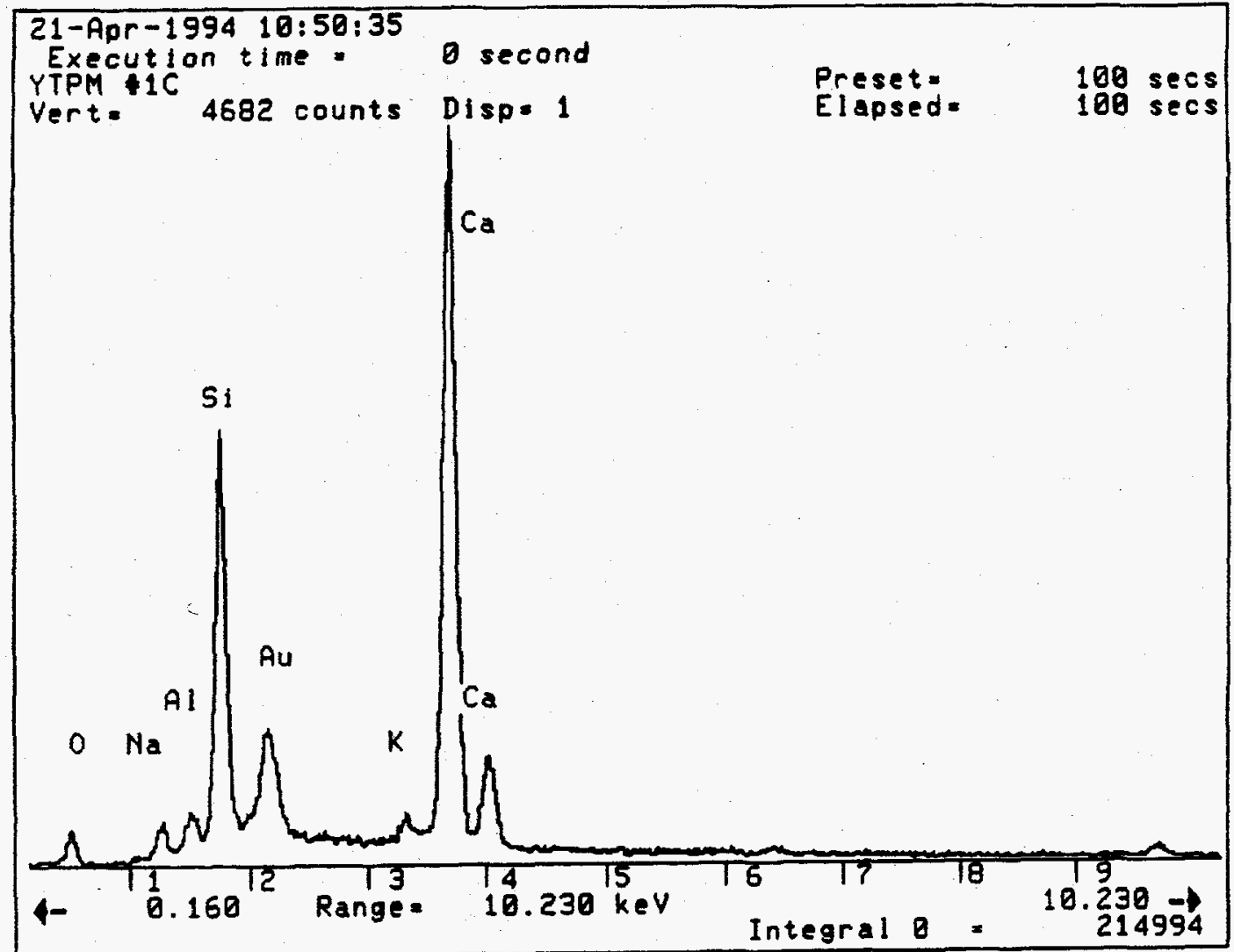

Figure 16. Energy Dispersive X-Ray Spectrum of Topopah Spring tuff coated sample showing higher calcium content. 


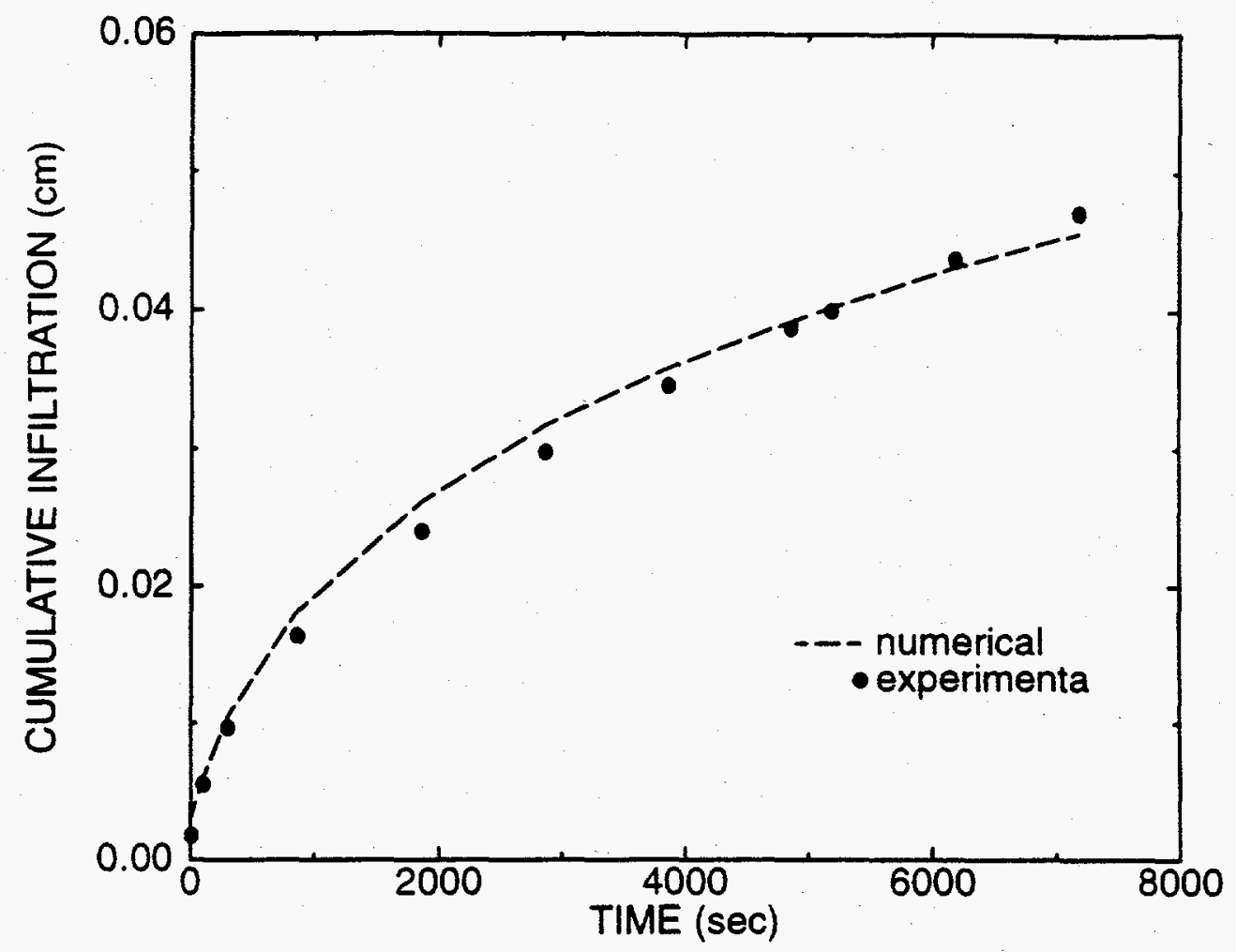

Figure 17. Comparison of simulated imbibition with experimental sorptivity data for a sample of Tiva Canyon coated fracture surface.

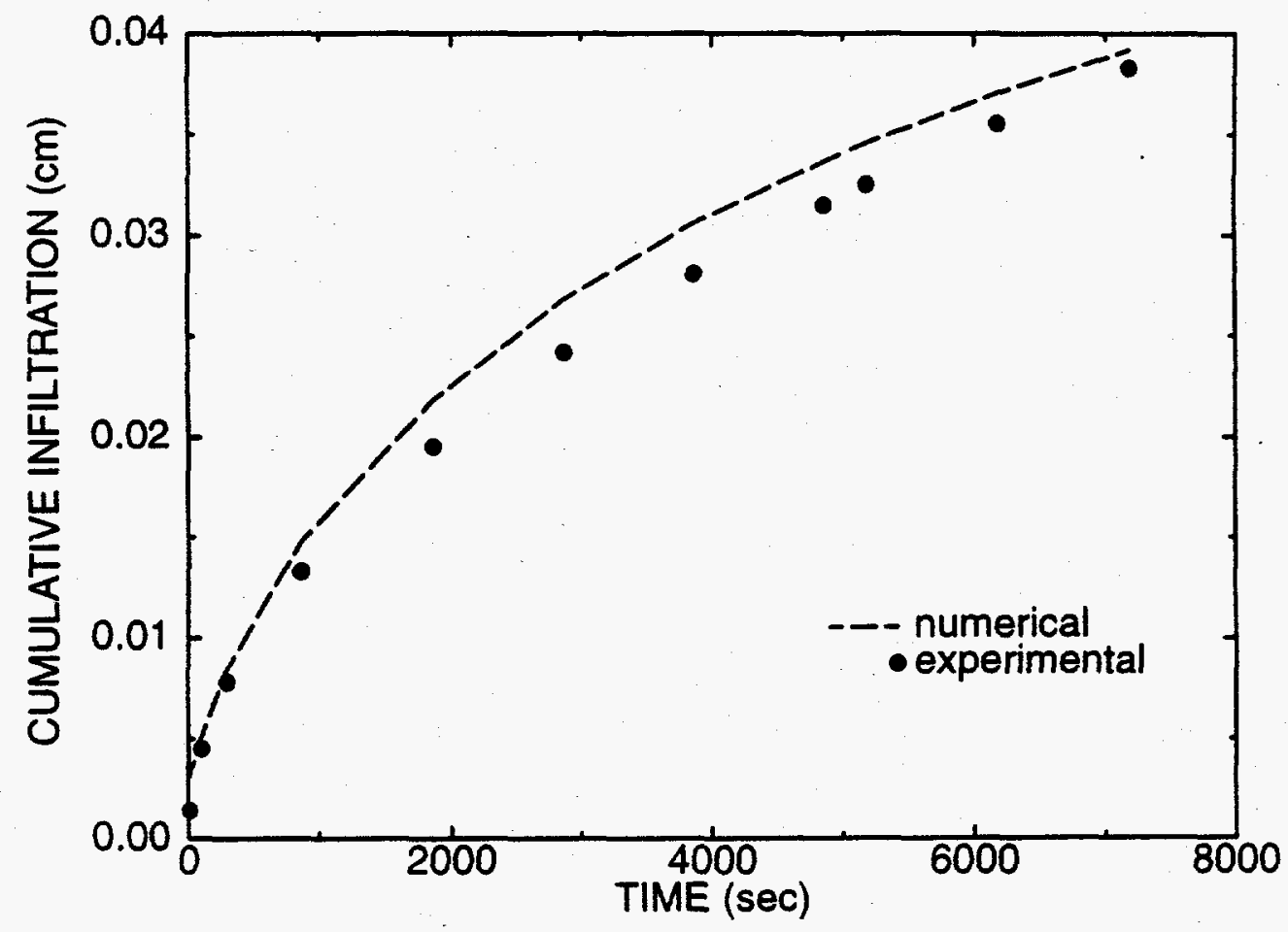

Figure 18. Comparison of simulated imbibition with average experimental sorptivity data for a sample of Tiva Canyon uncoated fracture surface. 


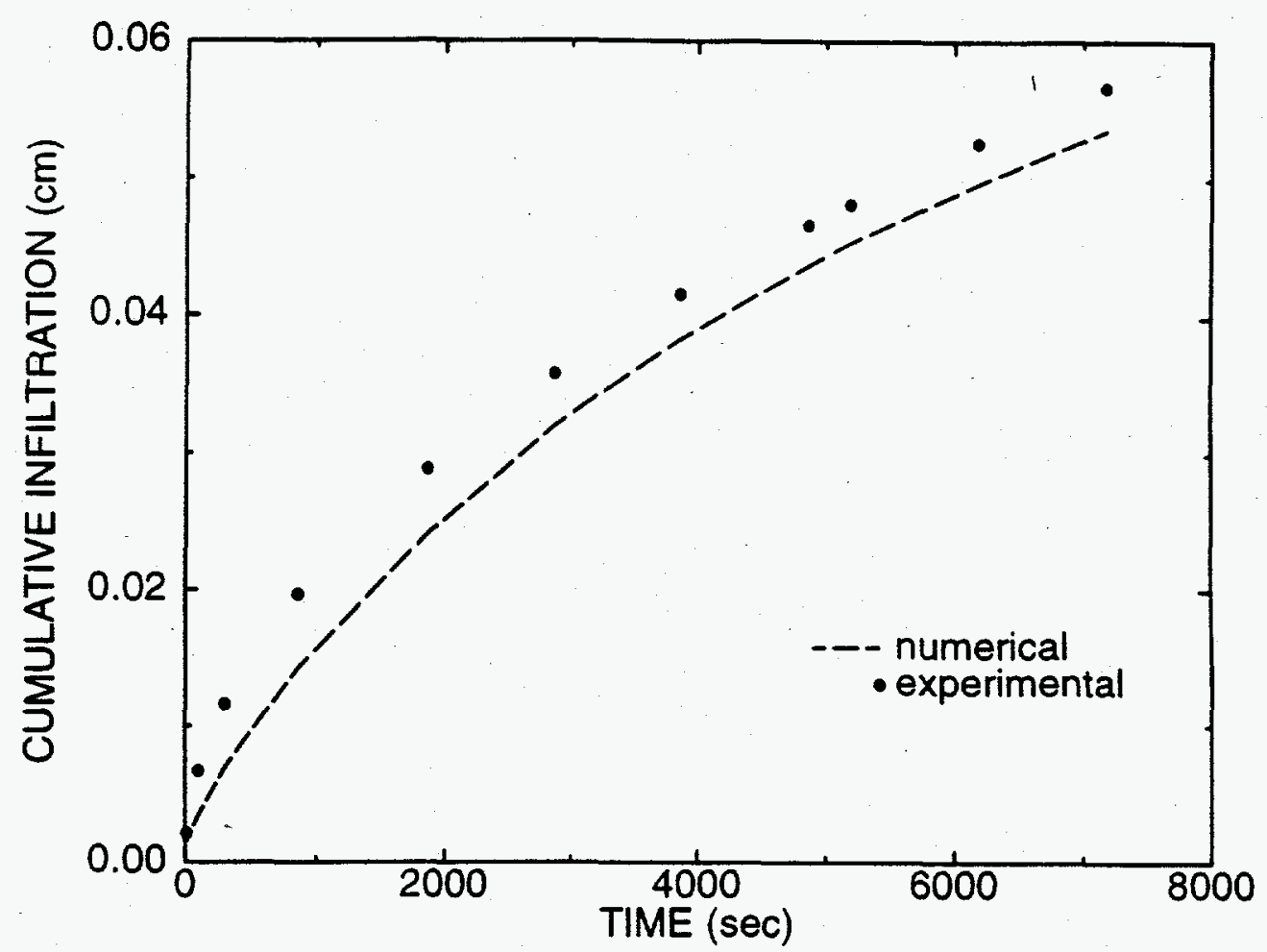

Figure 19. Comparison of simulated imbibition with average experimental sorptivity data for a sample of Topopah Spring coated fracture surface.

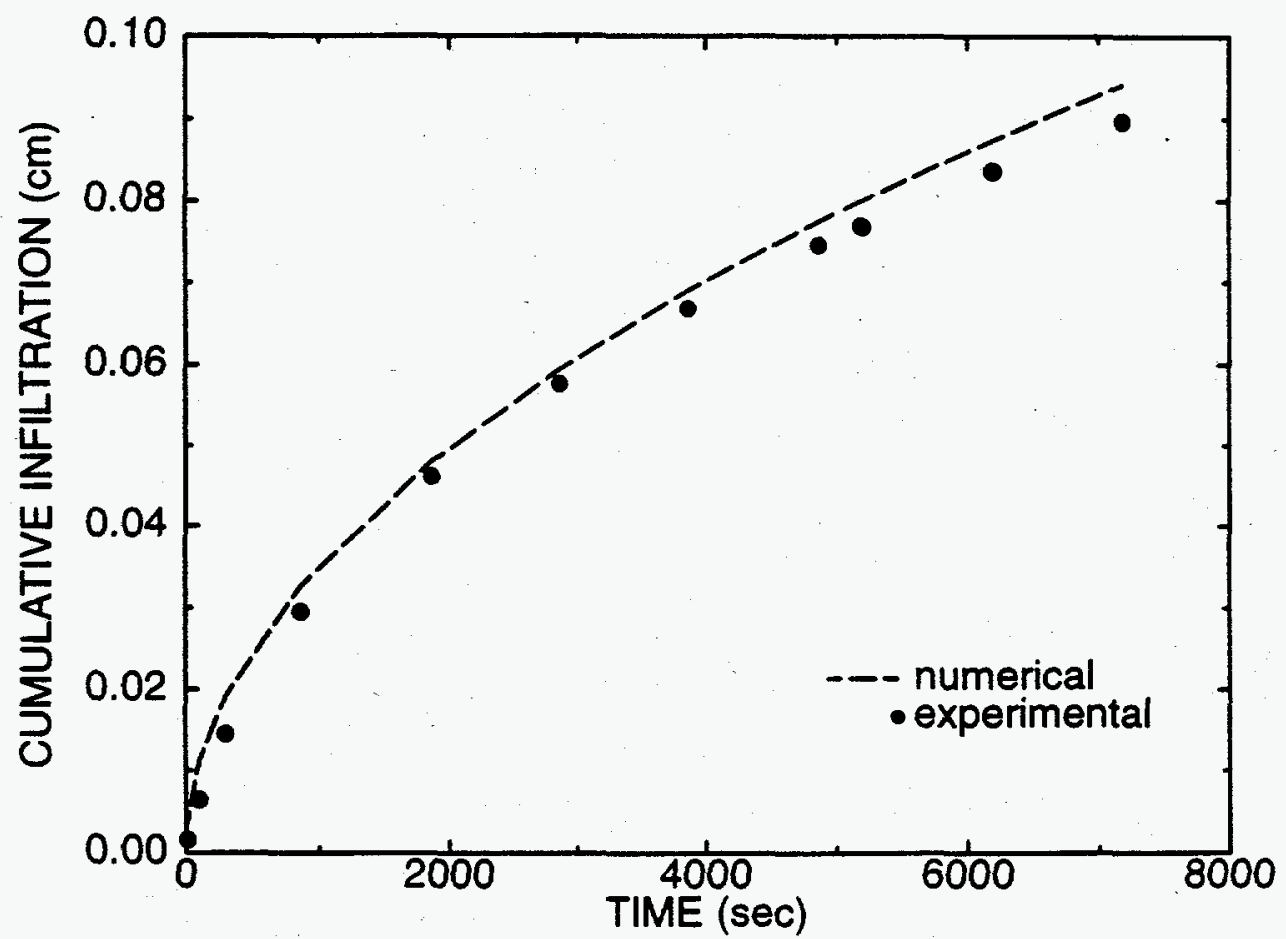

Figure 20. Comparison of simulated imbibition with average experimental sorptivity data for a sample of Topopah Spring uncoated fracture surface. 


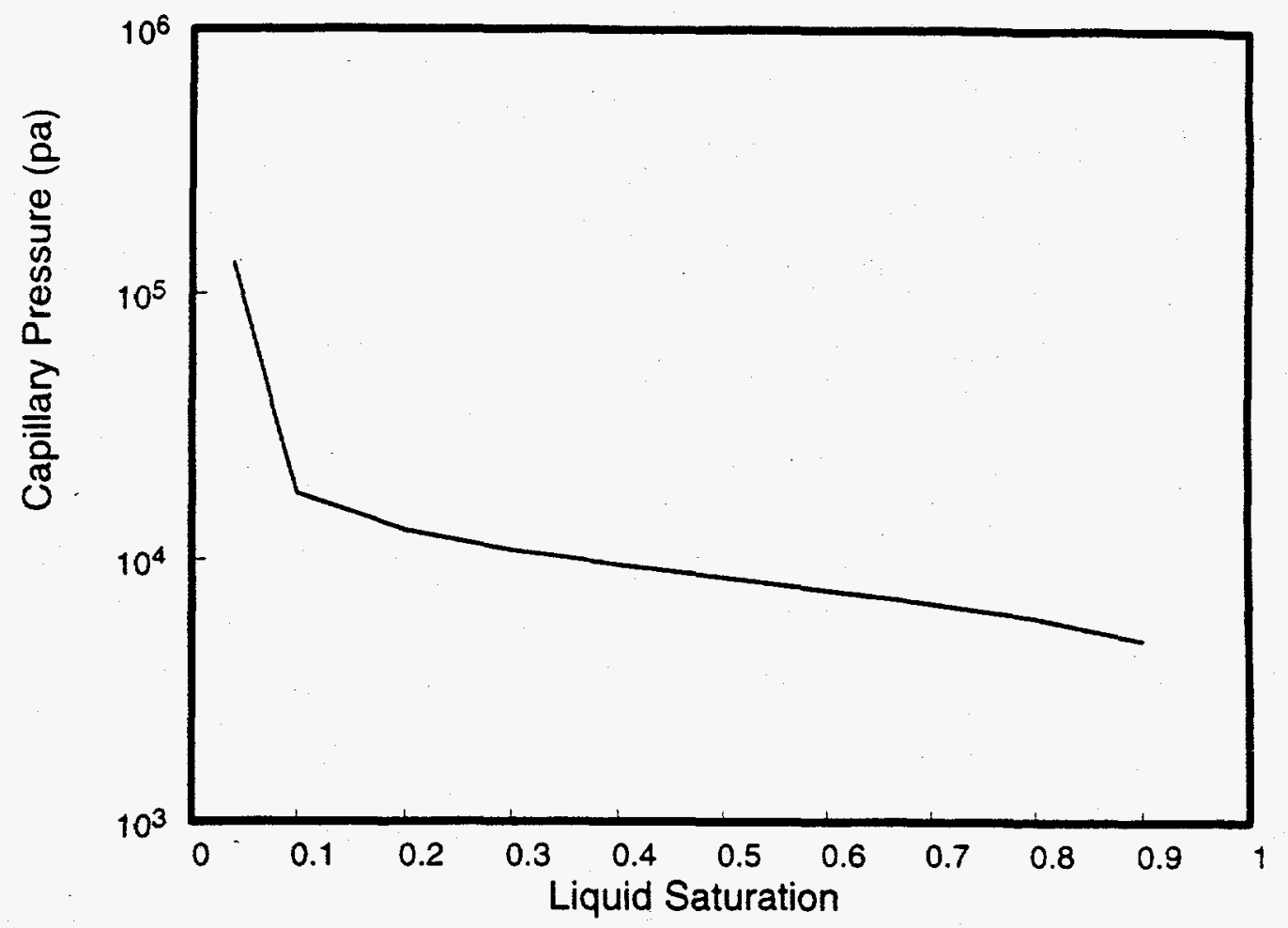

Figure 21. Retention model for the fracture used in simulations of both Tiva Canyon and Topopah Spring tuffs.

the retention curve and relative permeability models used for the Topopah Spring tuff matrix. Initial saturation in the Topopah Spring matrix was taken as 44 percent and the corresponding capillary pressure is roughly $8,000,000 \mathrm{pa}(8 \mathrm{MPa})$. While the initial saturation of the simulated imbibition was greater than that found in the laboratory experiments, it is more analogous to that found under natural field conditions. Figure 23 shows the capillary pressure model and relative permeability model used for the Tiva Canyon tuff matrix. The capillary pressure and relative permeability values at 44 percent initial saturation for Tiva Canyon matrix are slightly lower than for Topopah Spring matrix. The porosities for the matrix are taken from Rulon et al. (1986). The van Genuchten parameters used in the simulation are given in Table 4. The matrix saturated permeabilities are taken from numerical simulations necessary to match the experimental sorptivity data as discussed previously.

TABLE 4. MATRIX MODEL PARAMETERS

\begin{tabular}{llllcccc}
\hline \hline & & & & & \multicolumn{3}{c}{$k\left(\mathrm{~m}^{2}\right)$} \\
& $\lambda$ & $\mathrm{S}_{\mathrm{r}}$ & $\mathrm{S}_{\mathrm{L}}$ & $\alpha(\mathrm{pa})$ & $\eta$ & Coated & Uncoat \\
\hline Topopah Spring & 0.444 & 0.08 & 1.0 & $5.78 \mathrm{E}-7$ & 0.14 & $2.9 \mathrm{E}-18$ & $9.1 \mathrm{E}-18$ \\
Tiva Canyon & 0.358 & 0.002 & 1.0 & $8.37 \mathrm{E}-7$ & 0.12 & $2.3 \mathrm{E}-19$ & $1.3 \mathrm{E}-19$ \\
\hline \hline
\end{tabular}

\footnotetext{
$\mathrm{S}_{1}:$ Liquid saturation

$\eta$ : Porosity.

$\lambda$ and $\alpha$ : van Genuchten curve fit parameters

$k$ : Saturated permeabilities
} 

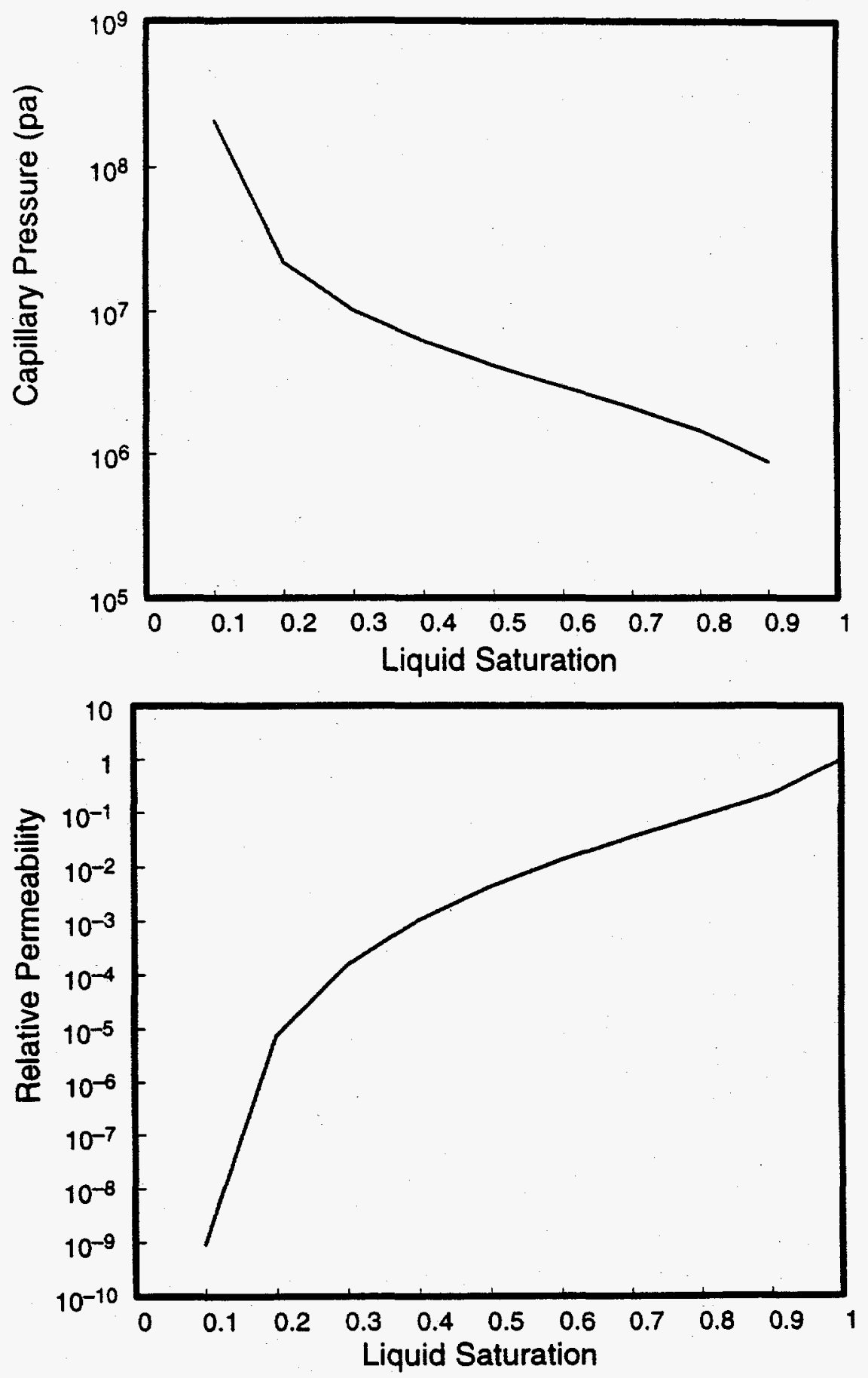

Figure 22. Water retention and relative permeability relationships used in the simulation for the Topopah Spring tuff. 

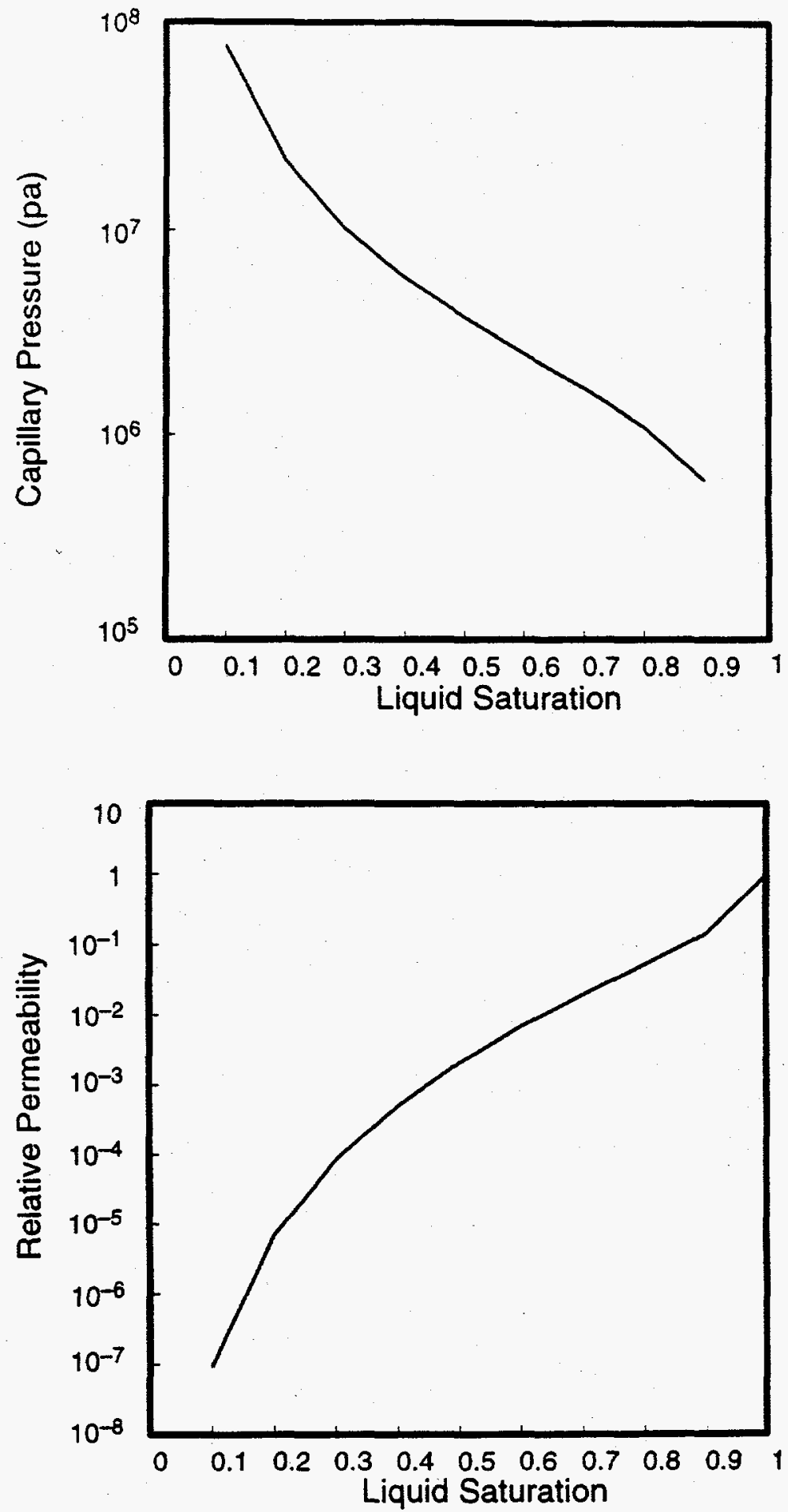

Figure 23. Water retention and relative permeability used in the simulation for the Tiva Canyon tuff. 
Simulations were run for two hours with a constant pressure head $(\mathrm{P}=0)$ at the top of the fracture. Wetting front travel depth was defined as 80 percent of full saturation in the fracture. The plot of wetting front travel depth versus time in the fracture ( 12 microns) for the Topopah Spring tuff (Figure 24) shows the wetting front in the coated fracture has traveled $26 \mathrm{~cm}$ after two hours, while in the uncoated fracture it has traveled about $20 \mathrm{~cm}$ after two hours. Note the resemblance of this plot to the time versus cumulative infiltration curves (Figures 6 and 8). Similarly, Figure 25 is the plot of wetting front travel depth versus time for the fracture in the Tiva Canyon tuff. Since the permeability of the Tiva Canyon tuff matrix is lower than that of Topopah Spring tuff, the wetting front travels deeper down the fracture. For the uncoated fracture, the wetting front reaches a depth of $51 \mathrm{~cm}$, while for the coated fracture it reaches a depth of $49 \mathrm{~cm}$. Recall that for Tiva Canyon tuff the average experimental sorptivity for the coated fracture surfaces was higher than the uncoated fracture surface sorptivity.

These results are in agreement with the experimental and statistical results. The laboratory experiments showed that the Topopah Spring tuff had higher average sorptivity compared to Tiva Canyon, while the statistical results showed that there is no significant difference in the sorptivity data between coated and uncoated fracture surfaces for Tiva Canyon tuff. On the other hand, there is significant difference in the sorptivity between the coated and uncoated fracture surfaces for the Topopah Spring tuff. This is reflected in the difference in depth to which the wetting front travelled in the Topopah Spring fracture for a coated fracture as compared to the uncoated.

The simulated water content distributions are also plotted as two-dimensional contour maps at the end of two hours. These maps clearly show horizontal and vertical movement of the wetting front when the fracture is coated and when it is not. Figure 26 shows the plot of water content distribution in the Topopah Spring tuff. Here, it is clear that the wetting front moves about $1.4 \mathrm{~cm}$ into the matrix in the uncoated fracture. In comparison, the wetting front travels only $1.2 \mathrm{~cm}$ into the matrix of the coated fracture. From the contour map of the wetting front travel distance for the coated fracture case of Tiva Canyon (Figure 27), it is evident that the wetting front in the matrix moves in only $0.38 \mathrm{~cm}$, while for the uncoated fracture it only moves $0.30 \mathrm{~cm}$ in the matrix. The smaller horizontal movement in the matrix for the uncoated fracture is due to lower permeability, as derived from experimental data.

The water content distribution (contour map) for the less permeable fracture $\left(\mathrm{k}=3 \times 10^{-12} \mathrm{~m}\right.$ ) for both coated and uncoated fractures for Tiva Canyon and Topopah Spring tuffs were similar in shape to the higher permeable fracture although the travel distances down the fracture were less.

In summary, the model results have shown that for Topopah Spring tuff, coating had a considerable effect on water imbibition and, consequently on the infiltration depth in the fracture. For the Tiva Canyon tuff, on the other hand, coating had only slight effect on the imbibition. However, due to its low matrix permeability, the depth of infiltration is much greater in the fracture for both coated and uncoated fractures in comparison to infiltration in the Topopah Spring tuff. The water content distribution plots for the narrow fracture show no difference in imbibition, but considerably reduce infiltration depth in the fracture. 


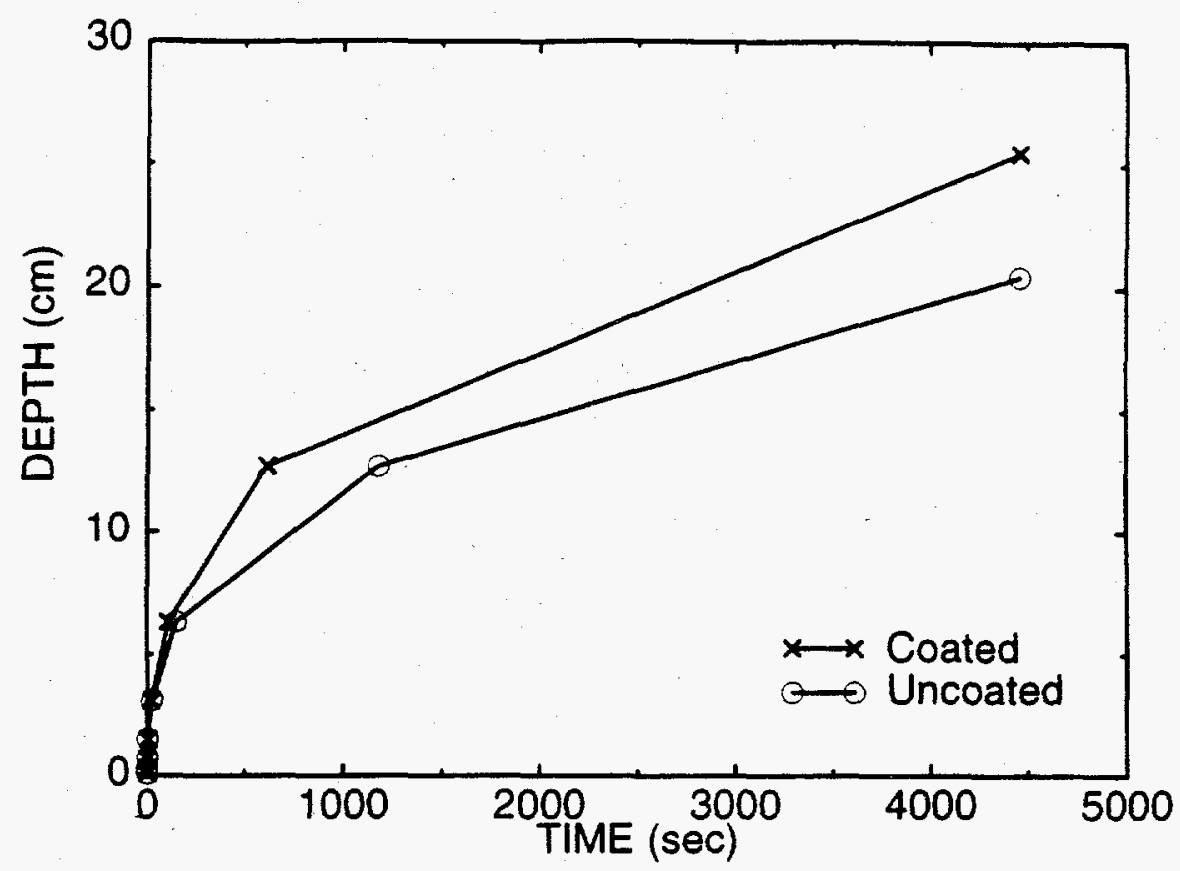

Figure 24. Depth versus time plot of infiltrating water in the Topopah Spring fracture showing lower depth of infiltration for uncoated fracture. The fracture appature is 12 microns.

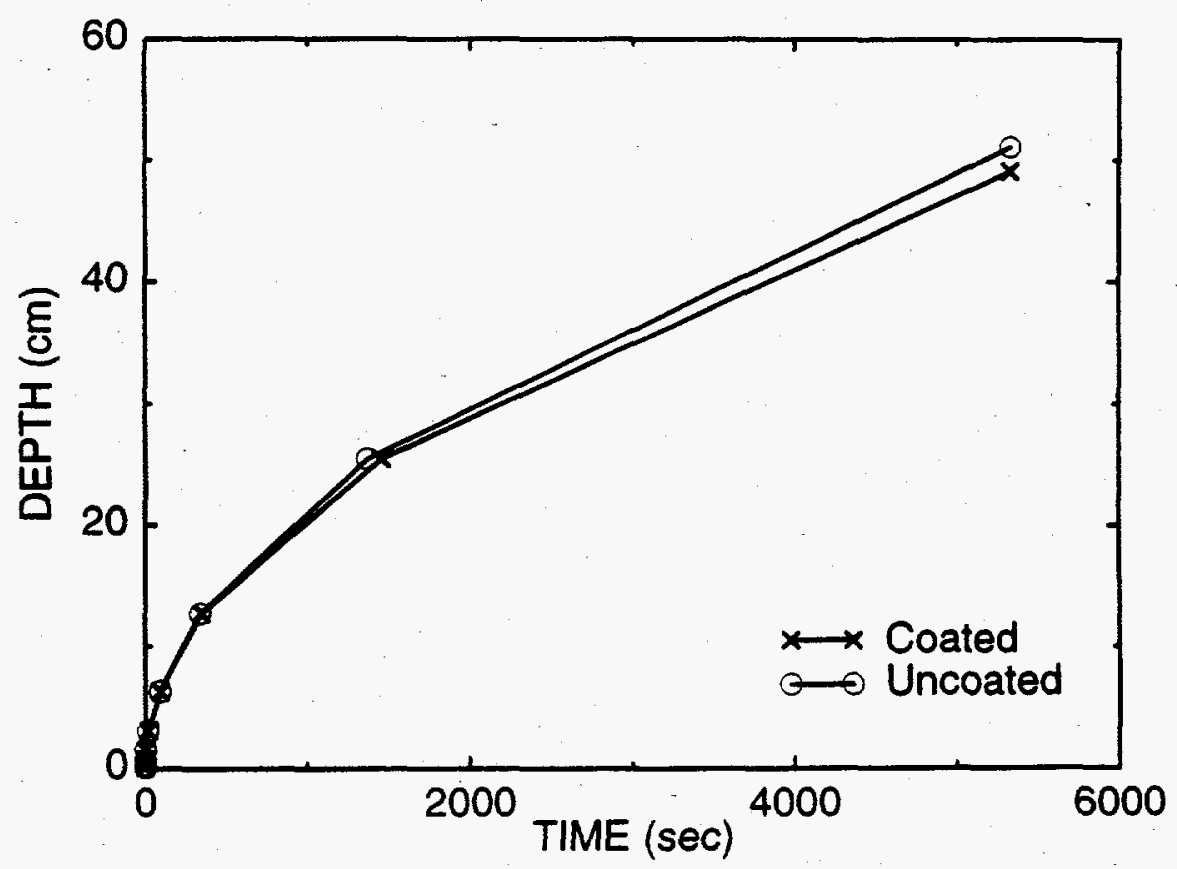

Figure 25. Depth versus time plot of infiltrating water in the Tiva Canyon fracture showing lower depth of infiltration for coated fracture. The fracture appature is 12 microns. 
a) Coated Fracture

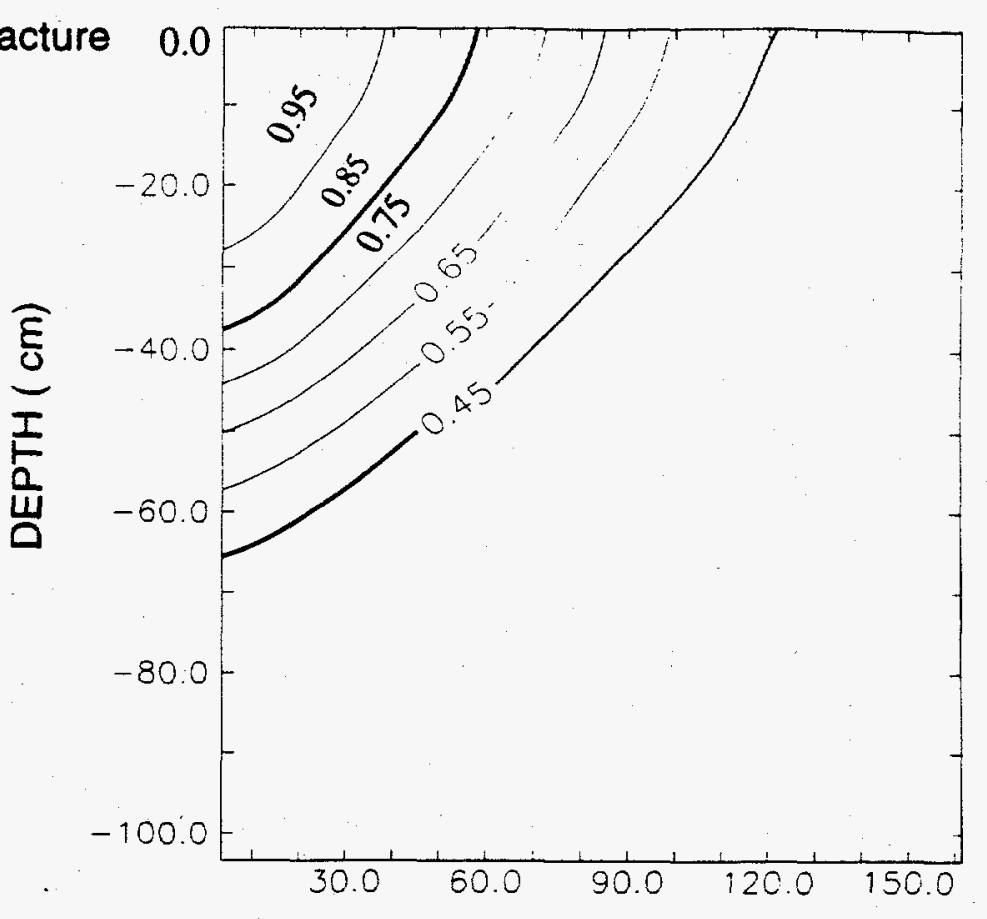

b) Uncoated Fracture

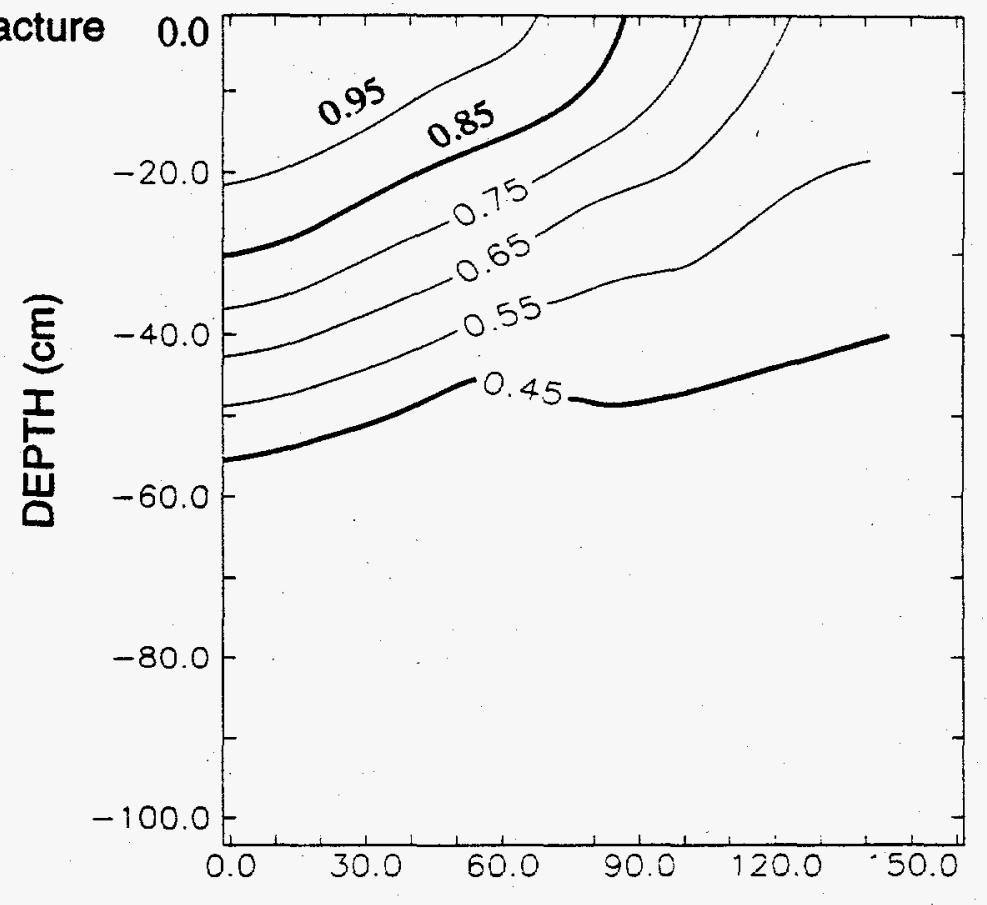

HORIZONTAL DISTANCE FROM FRACTURE $(\mathrm{cm}) \times 100$

Figure 26. Water saturation distribution in the Topopah Spring tuff after two hours of infiltration (fracture apature corresponds to 12 microns). 
a) Coated Fracture

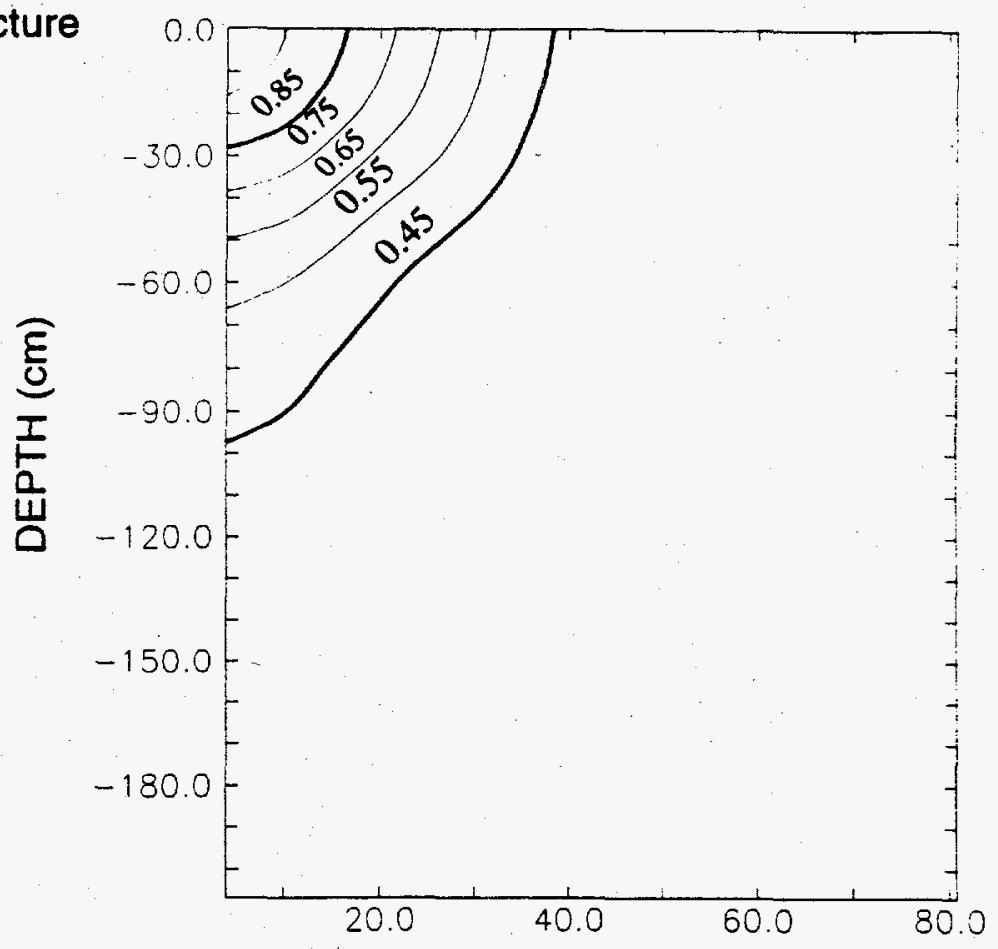

b) Uncoated Fracture

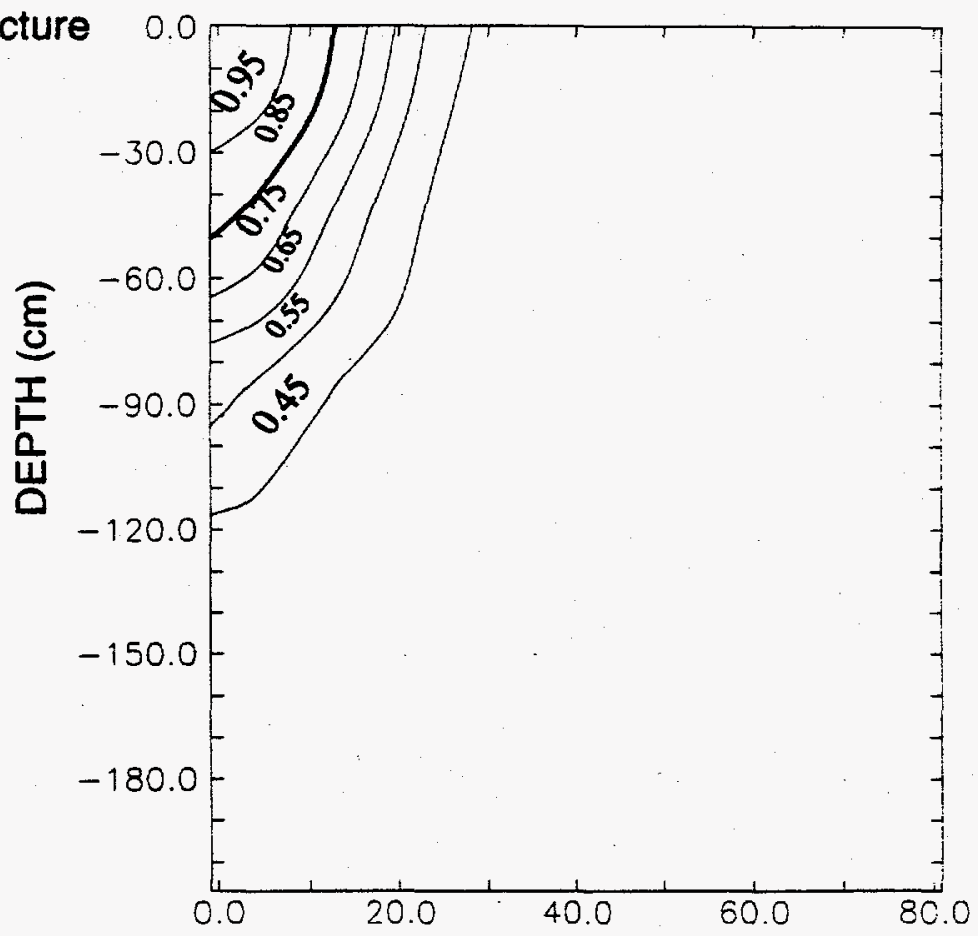

HORIZONTAL DISTANCE FROM FRACTURE $(\mathrm{cm}) \times 100$

Figure 27. Water saturation distribution in the Tiva Canyon tuff after two hours of infiltration (fracture apature corresponds to 12 microns). 
The modeling represents the case where the matrix blocks are initially very dry, which will produce the least wetting distance down the fracture. The matrix blocks at Yucca Mountain are often 80 to 90 percent saturated, which will result in much lower sorptivity values. Water in the fractures, therefore, will not be imbibed in the matrix block to the extent simulated above. Such high matrix saturations, coupled with coated fractures, may be the principal process controlling fast pathways suggested at Yucca Mountain (Fabryka-Martin et al., 1993). 


\section{CHAPTER 6: CONCLUSIONS}

The modified sorptivity cell proved to be an accurate experimental procedure to measure imbibition across naturally coated fracture surfaces. Sorptivity data clearly showed that significant differences in hydraulic properties between a coated fracture surface and an uncoated fracture surface can easily be measured. Sorptivities of Topopah Spring tuff are generally higher compared to sorptivities of Tiva Canyon tuff. The reason is that the average porosity and permeability were higher in the Topopah Spring tuff. There was a significant decrease in sorptivity due to fracture coatings in Topopah Spring samples. Results of Tiva Canyon tuff samples were contrary to our initial hypothesis that near-surface fracture coating may impede imbibition into the matrix. The higher infiltration across the fracture coatings is attributed to weathering beneath the coated fracture surface and a thin coating.

SEM analysis showed that coatings have an excess of iron, calcium, magnesium, and aluminum. SEM images showed larger surface porosity for uncoated samples and a smooth surface with interconnected cracks for coated samples. Statistically, the coating significantly reduced the sorptivity for Topopah Spring tuff, while the coating did not have significant effect on the sorptivity of Tiva Canyon tuff. There was no observed sample-to-sample variation for the Tiva Canyon samples. There was a slight difference between sample-to-sample variation for Topopah Spring samples because they were collected at three different locations approximately $300 \mathrm{~m}$ apart. The rock types, Tiva Canyon and Topopah Spring, were however significantly different towards imbibition.

Numerical results showed that Topopah Spring uncoated fractures had the least depth of wetting $(\sim 60 \mathrm{~cm})$ in the fracture and maximum horizontal imbibition distance into the matrix $(\sim 1.4$ $\mathrm{cm}$ ) for a fracture width of 12 microns. The coated fractures showed greater depth of wetting in the fracture and less imbibition into the matrix as compared to uncoated fractures. In the Tiva Canyon tuff, depth of wetting in the coated fracture was about $100 \mathrm{~cm}$ and horizontal imbibition distance in the matrix was $0.4 \mathrm{~cm}$. The depth of wetting in the uncoated fracture was about $130 \mathrm{~cm}$ and imbibition distance was only $0.3 \mathrm{~cm}$. Infiltration in the narrow fracture (6 microns) was less and horizontal distance in the matrix was the same as for the wider fracture for both coated and uncoated fractures.

The results of this work indicates that fracture coatings can significantly reduce the interaction between fracture and matrix water in Topopah Springs. This reduction can lead to far greater depths of penetration of water in the fractures at Yucca Mountain than previously predicted. Fracture coatings may effectively isolate much of the rock mass of Yucca Mountain for influencing the nature of water movement and may help explain the presence of recent ( $<30$ years old) pore waters found in the Calico Hills formation. 


\section{ACKNOWLEDGEMENTS}

This work was funded by the Nevada Agency for Nuclear Projects/Nuclear Waste Projects Office under Department of Energy grant DE-FGO8-85-NV 10461. The opinions expressed in this paper do not necessarily represent those of the State of Nevada or the U.S. Department of Energy. 


\section{REFERENCES}

Carlos, B.A., D.L. Bish and S.J. Chipera, 1991. Fracture Lining Minerals in the Lower Topopah Spring Tuff at Yucca Mountain, DE 91005901. Sandia Natl. Labs., Albuquerque, NM.

Fabryka-Martin, J.T., S.J. wightman, W.J. Murphy, M.P. Wickham, M.W. Caffee, G.J. Nimz, J.R. Southon and P. Sharma, 1994. Distribution of Chlorine-36 in the Unsaturated Zone at Yucca Mountain: An Indicator of Fast Transport Paths. Conference proceedings, FOCUS '93: Site Characterization and Model Validation; 26-29 September, 1993, Las Vegas, Nevada.

Fernandez, G.C.J., 1991. Advanced Statistical Methods, Unpublished Teaching Manual, Department of Agricultural Economics, University of Nevada, Reno, Nevada.

Flint. A.L., E.L. Flint and K.A. Richards, 1994. Evaluation of Measurement Scale Using Imbibition Experiments in Volcanic Tuffs, Soil Sci. Soc. of Amer. J., 58:94-102.

Flint, A., personal communication, 1992.

Foltz, S.D., V.C. Tidwell, R.J. Glass and S.R. Sobolik, 1993. Investigation of Fracture-Matrix Interaction: Preliminary Experiments in a Simple System, Proceedings of the Fourth Annual International High-Level Radioactive Waste Management Conference, Las Vegas, pp. 328-335.

Goldstein, J.I., D.E. Newbury, P. Echlin, D.C. Joy, C. Fiori and E. Lifshin, 1981. Scanning Electron Microscopy and X-Ray Microanalysis, pp 673, Plenum Press, New York.

Hillel, D., 1982. Introduction to Soil Physics. Academic Press. 364 pp.

Humphrey, M.D., J.D. Istok, L.E. Flint and A.L. Flint, 1993. An Improved Method for Measuring Imbibition Rates on Rock Core Samples, AGU Fall Abstracts.

Kilbury, R.K., T.C. Rasmusson, D.D. Evans and A.W. Warrick, 1986. Water and Air Intake of Surface-Exposed Rock Fractures Insitu, Water Resour. Res., 22(10):1431-1443.

Klavetter, E.A. and R.R. Peters, 1986. Estimation of Hydrologic Properties of an Unsaturated, Fractured Rock Mass, SAND84-2642, Sandia Natl. Lab., Albuquerque, New Mexico.

Linderfelt, W.R., 1987. Numerical Analysis of Infiltration and Near-Surface Percolation in Relation to Yucca Mountain, Nevada, Master's Thesis, Univ. of Nevada, Reno, Nevada..

Martin, R.J. III, R.H. Price, P.J. Boyd and R.W. Haupt, 1992. Anisotropy of the Topopah Spring Member Tuff, SAND91-0894, Sandia National Laboratories, Albuquerque, NM.

Martinez, M.J., R.C. Dykuizen and R.R. Eaton, 1992. The Apparent Conductivity for Steady Unsaturated Flow in Periodically Fractured Porous Media, Water Resour. Res., 28(11):2879-2887.

Moench, A.F., 1984. Double Porosity Models for a Fissured Groundwater Reservoir with Fracture Skin, Water Resour. Res., 20(7):831-846. 
Nagy, B., L.A. Nagy, M.J. Rigaliu, W.D. Jones, D.H. Krinsley and N.A. Sinclair, 1991. Rock Varnish in the Sonoran Desert: Microbiologically Mediated Accumulationm of Manganiferous Sediments, Sedimentology, 38:1153-1172.

Nitao, J.J. and T.A. Buscheck, 1991. Infiltration of a Liquid Front in an Unsaturated, Fractured Porous Medium, Water Resour. Res., 27(8):2099-2112.

Peters, R.R. and E.A. Klavetter, 1988. A Continuum Model for Water Movement in an Unsaturated Fractured Rock Mass, Water Resour. Res., 24(3):416-430.

Philip, J.R., 1957. The Theory of Infiltration: 4. Sorptivity and Algebraic Infiltration Equations, Soil Science, 84 , pp. 257-264.

Pruess, K., 1987. TOUGH user's guide, LBL-20700, Lawrence Berkeley Lab., Berkeley, CA.

Rasmussen, T.C. and D.D. Evans, 1993. Water Infiltration into Exposed Fractured Rock Surfaces, Soil Sci. Soc. of Amer. J., 57:324-329.

Rulon, J., G.S. Bodvarsson and P. Montazer, 1986. Preliminary Numerical Simulations of Groundwater Flow in the Unsaturated Zone, Yucca Mountain, Nevada, LBL-20553, Lawrence Berkeley Lab., Berkeley, CA.

Thoma, S.G., D.P. Gallegos and D.M. Smith, 1992. Impact of Fracture Coatings on Fracture/Matrix Flow Interactions in Unsaturated, Porous Media, Water Resour. Res., 28(5):1357-1367.

U.S. Department of Energy (DOE), 1988. Site Characterization Plan-Yucca Mountain Site, Nevada Research and Development Area, Nevada, DOE/RW-0199, Off. Civilian Radioactive Waste Mgt., Washington, D.C., 1988.

Walker, J. and S.K. Chong, 1986. Characterization of Compacted Soil Using Sorptivity Measurements, Soil Sci. Soc. of Amer. J., 50:288-291.

Wang, J.S.Y., N.G.W. Cook, H.A. Wollenberg, C.L. Carnahan, I. Javandel and C.F. Tsang, 1993. Geohydrologic Data and Models of Rainier Mesa and Their Implications to Yucca Mountain, HLRNWM Conference.

Wang, J.S.Y. and T.N. Narasimhan, 1985. Hydrologic Mechanisms Governing Fluid Flow in a Partially Saturated, Fractured, Porous Medium, Water Resour. Res., 21(12):1861-1874.

Zimmerman, R.W. and G.S. Bodvarsson, 1990. Combined Analytical/Numerical Approaches to Solving Fluid Flow Problems in the Unsaturated Zone at Yucca Mountain, HLRNWM Conference, 1990.

Zimmerman, R.W., G.S. Bodvarsson, A.L. Flint and L.E. Flint, 1993. An Inverse Procedure for Estimating the Unsaturated Hydraulic Conductivities for Volcanic Tuffs, HLRNWM Conference, 1993. 